\title{
Koštana industrija eneolitičkoga perioda u jugoistočnoj Europi \\ Bone industry in the Eneolithic period in the South-East Europe
}

\author{
Selena Vitezović \\ Arheološki institut, Beograd \\ Institute of Archaeology, Belgrade \\ s.vitezovic@ai.ac.rs
}

DOI: 10.17234/9789531758185-09

Uvod

Koštane sirovine u širem smislu obuhvaćaju sve tvrde sirovine životinjskog porijekla (animal hard tissue), točnije, tu pripadaju kosti, rogovi cervida, zubi, uključujući i bjelokost, ljušture mekušaca pa čak i ljuske jaja, oklop kornjača i materijali kertinastog sastava, kao što su rogovi bovida (cf. Averbouh 2000: 187; Christensen 2004).

Koštane sirovine imale su veliko značenje tijekom cijele prapovijesti, još od donjega paleolitika (cf. Schibler 2007). Mada se njihova uloga donekle mijenja tijekom vremena, a naročito uvođenjem novih sirovina i s razvojem metalurgije, one su i u mlađoj prapovijesti široko korištene za izradu raznovrsnih predmeta - kako svakodnevnog oruđa, oružja, tako i ukrasnih i neutilitarnih predmeta.

Nažalost, koštana industrija eneolitičkoga perioda slabo je proučena, osobito u jugoistočnoj Europi. Poseban problem za analize jest stanje zbirki s iskopavanja sprovedenih u 19. i u prvoj polovici 20. stoljeća, tijekom kojih faunalni nalazi nisu pažljivo prikupljani, već samo odabrani, cijeli i/ili atraktivni predmeti. Pored toga, prisutan je problem vezan za nepotpune podatke o kontekstu i stratigrafiji, osobito kod višeslojnih lokaliteta.

\section{Introduction}

Osseous raw materials in wide sense include all the hard animal tissue, more precisely, bones, cervid antlers, teeth, including ivory, mollusc shells, and even shells of eggs, tortoise shells and keratinous materials, such as bovid horns (cf. Averbouh 2000: 187; Christensen 2004).

Bone raw materials were very important throughout the entire prehistory, since the Lower Palaeolithic (cf. Schibler 2007). Although their role changed over time, especially with the introduction of the new raw materials and the development of the metallurgy, they were still used in the later prehistoric times for production of a variety of objects everyday tools and weapons, as well as decorative and non-utilitarian items.

Unfortunately, the bone industry in the Eneolithic is not sufficiently explored, in particular in the SouthEast Europe. A considerable obstacle for analyses is the state of the assemblages originating from excavations carried out in the 19th and the first half of the 2oth century, when the faunal remains were not carefully recovered, but only selected, complete and/or attractive objects. Furthermore, there is a problem of incomplete information regarding the context and the stratigraphy, especially when it concerns multi-layered sites. 
U ovom radu bit će dan pregled raspoloživih podataka o koštanim industrijama tijekom eneolitičkog perioda u različitim kulturama koje su naseljavale prostor jugoistočne Europe, točnije, područje južnoga Karpatskog bazena i zapadnog, centralnog i istočnog Balkana - u badenskoj, kostolačkoj, Cernavoda i vučedolskoj kulturi, i u okvirima kulturnog kompleksa Bubanj-Sălcuța-Krivodol.

\section{Kulture Baden i Baden-Boleráz}

Koštani artefakti badenske kulture i njezinih lokalnih varijacija poznati su nam s više lokaliteta u Mađarskoj.

Na višeslojnom lokalitetu Kaposújlak-Várdomb u jugozapadnoj Mađarskoj pronađena je razmjerno bogata zbirka koštanih predmeta, od čega oko 35 pripada slojevima kulture Pécel-Baden (Gál 2011). Uglavnom su korištene kosti ovce i koze, osobito metapodijalne kosti i tibije, dok je šest predmeta izrađeno od rogova jelena. Tipološki repertoar dosta je ograničen, prevladavaju artefakti sa šiljatim radnim dijelom (23 primjerka) - masivni, srednji i fini šiljci, od čega jedan s perforacijom na baznom dijelu. Dosta su neobična i dva predmeta izrađena od rijetko korištenih sirovina - jedan šiljak od fibule divlje svinje i jedan izrađen od tibije zeca (Gál 2011: 139-140). Još treba spomenuti dva masivna predmeta, sjekire ili tesle od većih segmenata roga jelena. Jedan, fragmentirani predmet, izrađen je od segmenta stabla i ima kružnu perforaciju na baznom dijelu. Drugi predmet izrađen je od baze i segmenta stabla, ima dosta naglašeno modificiranu bazu i ima razmjerno veliku perforaciju gotovo pravokutnog oblika (Gál 2011: sl. 6).

$\mathrm{Na}$ lokalitetu Balatonőszöd-Temetői-Dűlő pronađeno je oko 120 artefakata, od čega 26 pripada Boleráz, a veći dio, gotovo 100, badenskoj kulturi (Gál 2014).

U horizontu Boleráz prevladavaju fini i srednji šiljci; najbrojniji podtip su šila od po dužni cijepanih tibija i metapodijalnih kostiju sitnih preživača bez epifize na bazi. Ulne su također korištene, nađen je jedan fini šiljak od ulne psa i jedan dvojni šiljak od ulne krupnog preživača. Razmjerno su brojna i dlijeta, izrađivana od rebara, ulni i drugih kostiju. Neobičan je predmet izrađen od iliuma psa forme spatule, nepoznate funkcije. Od zuba svinje izrađen je jedan strugač i jedan privjesak, s perforacijom promjera od svega $2 \mathrm{~mm}$ na vrhu, kao i
In this paper will be offered an overview of the available data on the bone industries in the Eneolithic among the diverse cultures that inhabited the area of the South-East Europe, more specifically, the region of the south Carpathian basin and the western, central and eastern Balkans - within Baden, Kostolac, Cernavoda and Vučedol culture, as well as within the cultural complex Bubanj-SălcuțaKrivodol.

\section{Baden and Baden-Boleráz cultures}

Bone artefacts of the Baden culture and its local variants are known from several sites in Hungary.

On the multi-layered site of Kaposújlak-Várdomb in the south-west Hungary was discovered relatively rich assemblage of osseous artefacts, out of which about 35 objects belongs to the layers of the PécelBaden culture (Gál 2011). Mainly sheep and goat bones were used, especially metapodial bones and tibiae, while six objects were made from red deer antlers. The typological repertoire is rather limited; pointed tools ( 23 specimen) - large, medium and fine points, one of them with perforation at the basal part. There are two unusual items, made from rarely used skeletal elements - one point from wild pig fibula and one point from hare tibia (Gál 2011: 139-140). Also two massive objects should be mentioned, axes or adzes made from large segments of red deer antlers. One of them, fragmented, was made from beam segment and had circular perforation at the basal part. The other object was made from the segments of the base and beam, it has heavily modified basal part and relatively large rectangular perforation (Gál 2011: fig. 6).

On the site of Balatonőszöd-Temetői-Dülő approximately 120 artefacts were recovered, out of which 26 belongs to the Boleráz, and the majority, almost 100 objects, to the Badn culture (Gál 2014).

Within Boleráz horizon fine and medium points predominate; the most common subtype are awls made from longitudinally split tibiae and metapodial bones from small ruminants without the epiphysis at the base. Ulnae were used as well, one fine point made from dog ulna was found and one double point from large ruminant ulna. Relatively frequent are chisels, made from ribs, ulnae and other bones. There was also one unusual item made from dog ilium, spatula-shaped, of unknown function. Pig teeth were used to manufacture one scraper and one pendant, with the diameter of the 

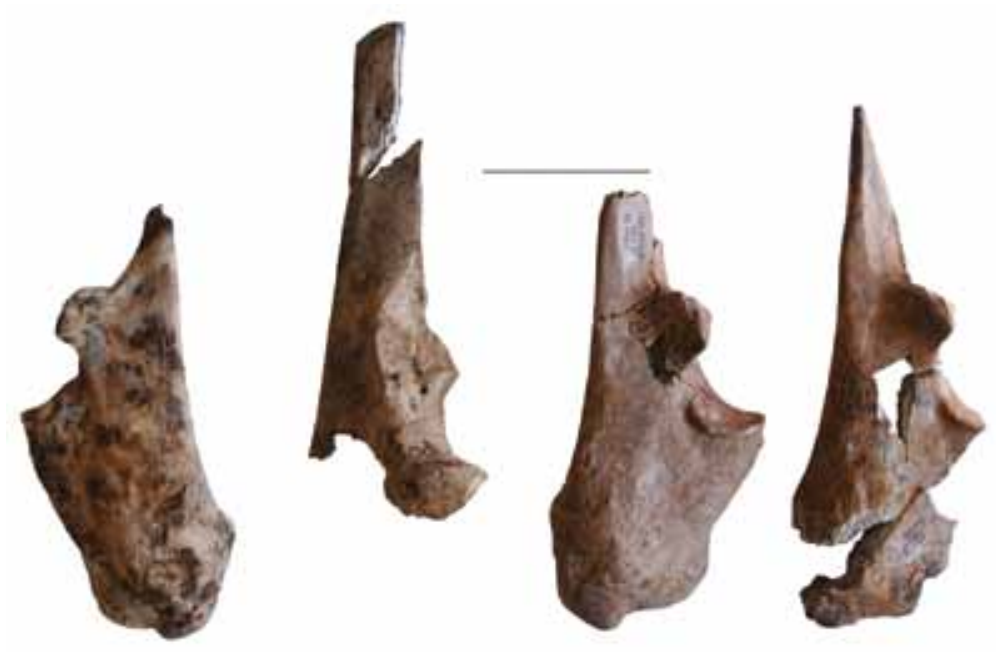

Slika / Figure 1. Šiljci i dlijeta od ulni, Gravinjak-Josipovac, badenska kultura. Points and chisels made from ulnae, Gravinjak-Josipovac, Baden culture (foto / photo: K. Miculinić).

nekoliko predmeta nejasne namjene. Rogovi nisu česti; ukupno dvije fragmentirane alatke su od roga jelena. Jedna je izrađena od baze i stabla odbačenog roga, druga od segmenta stabla, i obje su prelomljene na perforaciji.

U badenskom horizontu također su fini i srednji šiljci najzastupljeniji; najbrojnija varijanta jesu šila od tibija i metapodijalnih kostiju sitnih preživača, neki s očuvanom epifizom na baznom dijelu (oko 30 primjeraka). Ulne su također korištene za finije šiljke, uglavnom od ovce/koze, ali je prisutna i jedna ulna praseta. Među masivnim šiljcima treba spomenuti jedan od ulne govečeta i jedan od metapodijalne kosti jelena s očuvanom epifizom na baznom dijelu. Dlijeta su takođe razmjerno brojna (16 primjeraka), pretežno od rebara i segmenata dugih kostiju. Osim toga, nađena su i dva retušera, kao i jedan projektil. Od kanina svinje izrađeno je nekoliko predmeta, ali njihova namjena nije jasna.

Rogovi su nešto brojniji nego u horizontu Boleráz; ukupno četrnaest predmeta, svi od jelenjeg roga, osim jednog ad hoc dlijeta od roga srndaća. U pitanju su tesle i sjekire s kružnim perforacijama za drveni držak. Također je nekoliko dvojnih šiljaka izrađeno od segmenta roga, moguće korištenih kao projektili. perforation of only $2 \mathrm{~mm}$, as well as few items of unknown purpose. Antlers are not common; total of two fragmented axes made from red deer antler were found. One was made from the basal part of the shed antler, the other from beam segment, and both were broken on the perforation.

Within the Baden horizon also fine and medium points prevail; the most common variant are awls made from tibiae and metapodial bones of small ruminants, some with epiphysis preserved at the base (approximately 30 specimens). Ulnae were also used for fine points, mainly from sheep/goats, but also one pig ulna was noted. Among the heavy points should be mentioned one made from cattle ulna and one made from red deer metapodial bone, with the epiphysis preserved at the base. Chisels are also relatively frequent (16 specimen), usually made from ribs and long bone segments. Also two retouching tools were recovered, and one projectile points. Boar tusks were also used for production of several artefacts, but their function is unknown.

Antlers are slightly more common than within Boleráz horizon; total of fourteen objects were found, all from red deer, except for one ad hoc chisel made from roe deer antler. These were axes and adzes with circular perforations for a wooden handle. Also several double points were made from antler segments, probably used as projectile points. 


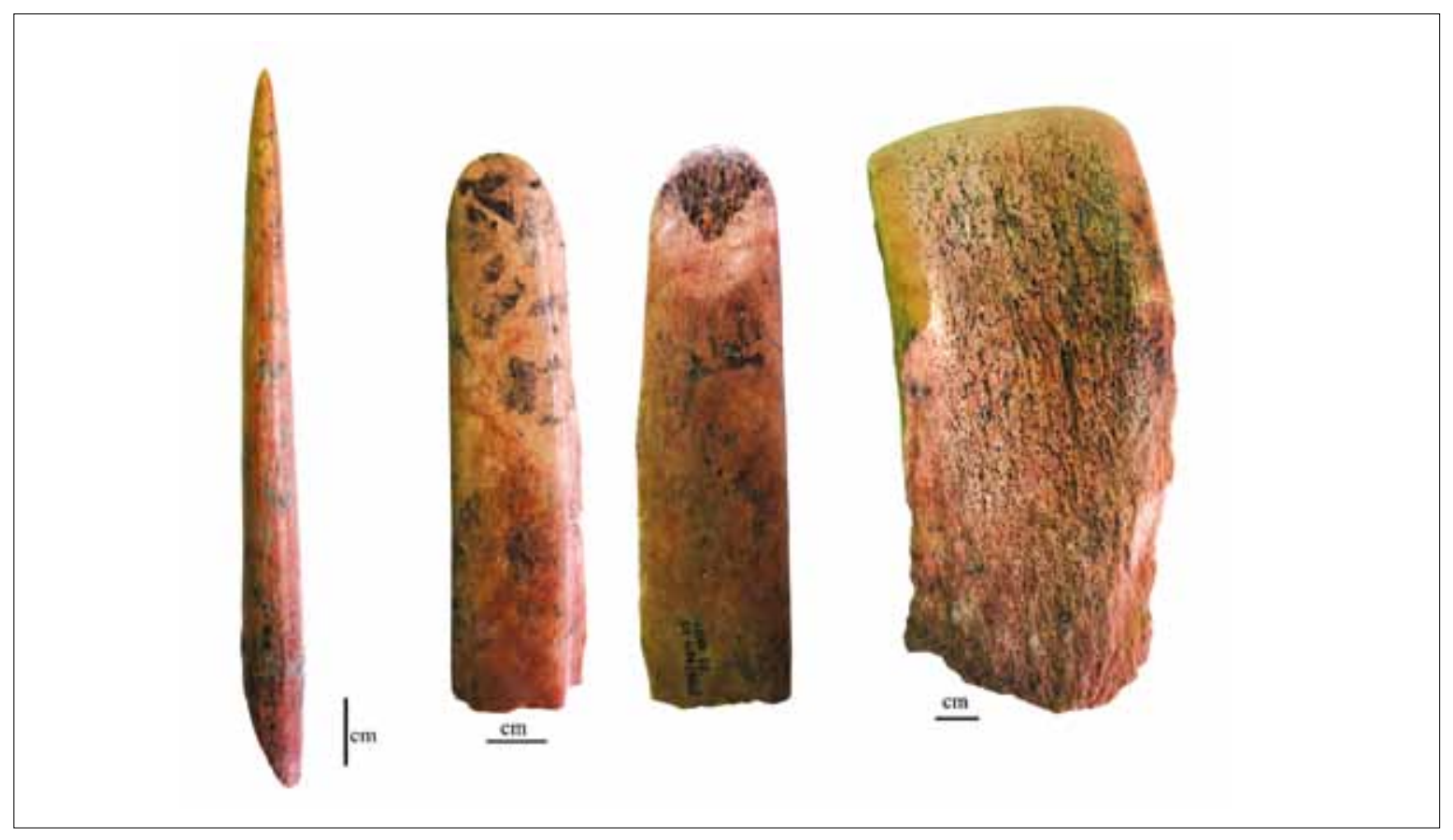

Slika / Figure 2. 1) projektil, 2) strugač od rebra, 3) sjekira ili tesla od roga jelena, Gravinjak-Josipovac, badenska kultura. / 1) projectile point, 2 ) scraper made from rib, 3) axe or adze made from red deer antler, Gravinjak-Josipovac, Baden culture (foto / photo: S. Vitezović).

S lokaliteta Boleráz kulture Gyõr-Szabadrét-Domb u jugozapadnoj Mađarskoj potječe zbirka od oko 120 predmeta (Choyke 2014). Uglavnom su korištene kosti; u manjoj mjeri su prisutni rogovi jelena i kanini svinje. Tipološki, prisutna su šila od metapodijalnih kostiju sitnih preživača, šila od rebara, masivniji probojci od dugih kostiju, spatule, klinovi, dlijeta od različitih dugih kostiju, osobito ulni i drugih dugih kostiju. Prisutno je i oružje - fino oblikovane koštane strelice, zatim dvostruki šiljci izrađivani uglavnom od dugih kostiju krupnih preživača, korišteni kao vrhovi za projektile, kao i jedan konusni harpun od paroška roga (Choyke 2014: fig. 9, fig. 13, fig. 18).

Rogovi jelena korišteni su za izradu masivnijeg alata; od bolje očuvanih primjeraka treba spomenuti sjekiru/teslu od baze i stabla odbačenog roga sa četvrtastom perforacijom i sjekiru ili sjekiru-čekić također od odbačenog roga, dosta modificiranog baznog dijela i također s perforacijom četvrtaste forme (Choyke 2014: fig. 19).

Od kanina svinje, i to kako domaće, tako i divlje, izrađivani su strugači S-forme. Još je interesantna pojava mandibula korištenih u izradi kožnih remenova thong stretcher / thong smoother), čak 10 primjeraka je pronađeno. Ukrasi su rijetki; nađen je jedan privjesak od kanina svinje i deset perfo-
From Boleráz site of Gyõr-Szabadrét-Domb in the south-western Hungary originates an assemblage of 120 objects (Choyke 2014). Mainly bones were used; red deer antlers and boar tusks were used to a lesser extent. Typologically are represented awls from small ruminant metapodial bones, awls made from ribs, heavy points from long bones, spatulae, wedges, chisels from diverse bone segments, especially from ulnae and other long bones. Also weapons were present - finely made bone arrowheads, double points from large ruminant long bones, used as projectile points, as well as one toggle shaped harpoon made from antler tip (Choyke 2014: fig. 9, fig. 13, fig. 18).

Red deer antlers were used for massive tools; among the better preserved artefacts should be mentioned one axe/adze from the basal and beam segment of a shed antler with rectangular perforation, and one axe or hammer-axe from shed antler, with heavily modified basal part and also with rectangular perforation (Choyke 2014: fig. 19).

Both wild and domestic pig canines were used for production of S-shaped scrapers. Also is interesting the occurrence of the mandibles used for production of leather thongs, so-called thong stretchers or thong smoothers; total of 10 items were discovered. Decorative objects are rare; one pendant 
riranih zuba od domaćeg psa i od lisice. Otpaci od proizvodnje također su konstatirani, što pokazuje da su predmeti izrađivani unutar naselja (Choyke 2014).

Koštana industrija badenske kulture u Slavoniji poznata nam je s lokaliteta Gravinjak kod Josipovca (Miculinić \& Vitezović 2017). Tijekom 2007. godine sprovedena su zaštitna arheološka istraživanja na ovom lokalitetu, prilikom izgradnje autoceste Beli Manastir-Osijek-Svilaj. Otkriveni su ostaci jednoslojnog naselja - otpadne i druge jame, ukopani stambeni objekti; a nađen je i jedan dječji grob (Mihelić 2008: 15-17; Miculinić \& Vitezović 2017; Miculinić \& Vitezović, u pripremi).

Analiza faunalnih ostataka pokazala je dosta visok udio divljih životinja, oko $60 \%$ (ukoliko se ne uračunaju ostaci jednog goveda koje je cijelo pohranjeno). Od divljih vrsta, najzastupljeniji je jelen, potom srndać, a prisutni su i divlja svinja i divlje govedo. Među domaćim životinjama najzastupljeniji su svinja i govedo, dok su ovce i koze prisutne u manjoj mjeri. Pažljivim pregledom faunalnih ostataka izdvojeno je gotovo stotinu artefakata, mada su neki dosta fragmentirani i loše očuvanih površina zbog izloženosti eroziji i drugim tafonomskim utjecajima. Od sirovina, uglavnom su zastupljene različite kosti goveda, ovce/koze i jelena - metapodijalne, ulne i druge duge kosti, ali su prisutne $i$ plosnate kosti - rebra, skapule i pelvisi. Manji broj predmeta izrađen je od segmenata roga jelena i od kanina svinje.

Tipološki repertoar uključuje različite zašiljene alatke - šila od po dužini cijepanih dugih kostiju, dok su od ulne goveda izrađivani masivniji probojci. Od ulni su izrađena i manja dlijeta s dosta naglašenim tragovima upotrebe (SI. 1). Glačalice i strugači izrađivani su od po dužini cijepanih dugih kostiju, kao i od segmenata rebara, na kojima se jasno vidi naglašena istrošenost na distalnom dijeIu (SI. 2/2). Svi ovi predmeti korišteni su na mekim organskim materijalima - za obradu kože, krzna i biljnih vlakana (cf. Peltier 1986; Legrand 2007).

Dosta su neuobičajeni segmenti skapula i pelvisa s tragovima uporabe, za koje zasad ne postoje poznate paralele s drugih eneolitičkih nalazišta. Uglavnom se radi o nepravilnim urezima i linijama i moguće je da su korišteni kao neka vrsta radne površine, odnosno podmetača ili podloge. made from pig canine was found, as well as ten perforated teeth from domestic dog and from fox. Production waste was recovered as well, showing that these objects were produced within the settlement (Choyke 2014).

Bone industry of the Baden culture in Slavonia is known from the site of Gravinjak near Josipovac (Miculinić \& Vitezović 2017). During 2007 rescue archaeological excavations were carried out on this site, during the construction of the motorway Beli Manastir-Osijek-Svilaj. The remains of singlelayered settlement were discovered - rubbish and other pits, dug-out dwellings; and also one child grave was discovered (Mihelić 2008: 15-17; Miculinić \& Vitezović 2017; Miculinić \& Vitezović, in prep.).

The analysis of the faunal remains showed relatively high ratio of wild animals, approximately $60 \%$ (if we do not count in the remains of a complete cattle skeleton). From wild species, the most frequent was red deer, followed by roe deer, and also wild pig and aurochs were present. Among the domestic species, pigs and cattle were the most common, while sheep and goats were present to a lesser extent. Careful examination of the faunal remains enabled to single out almost one hundred of artefacts, although some of them are heavily fragmented and badly preserved, with eroded surfaces. The most common raw material were different bones from cattle, sheep/goats and red deer - metapodial, ulnae and other long bones, but also flat bones - ribs, scapulae, pelvis. A small number of items was produced from red deer antler segments or from boar tusks.

The typological repertoire includes diverse pointed tools - awls from longitudinally split long bones and heavy points from cattle ulnae. Ulnae were also used to produce smaller chisels, usually heavily worn from use (Fig. 1.). Burnishers and scrapers were made from longitudinally split long bones and from rib segments, and also their distal ends display intensive traces of use (Fig. 2/2). All these tools were used on soft organic materials - for processing leathers, hides and plant fibres (cf. Peltier 1986; Legrand 2007).

Quite unusual is the occurrence of the segments from scapula and pelvic bones with traces of use, for which there are no parallels from other Eneolithic sites. The use wear consists mainly from irregular lines and incisions, and it is possible that these objects were used as some sort of a working surface - as a supporter or an anvil. 
Posebno još treba spomenuti jedan gotovo potpuno očuvani projektil, izrađen od duge kosti krupnog preživača (SI. 2/1). Predmet ima pun, kružni presjek, na distalnom dijelu ima masivni šiljak, dok je sama baza oštećena, i na tijelu predmeta se raspoznaju fine linije od struganja kremenom alatkom. Tipološki i tehnološki, srodan je projektilima pronađenima na lokalitetu Gyõr-Szabadrét-Domb.

Od alatki izrađenih od roga jelena, dvije bolje očuvane mogu se izdvojiti. Jedna je dlijeto od paroška roga, gdje je prirodni vrh roga dotjeran u sječicu, fino uglačan $i$ istrošen upotrebom, moguće za obradbu drveta. Drugi predmet je masivnija alatka za sječenje, sjekira ili tesla (SI. 2/3). Izrađen je od segmenta stabla roga. Distalni dio je dobiven tako što je rog ukoso isječen i struganjem i glačanjem formirana ravna, oštra radna ivica. Bazni dio nije očuvan. Perforacije nisu postojale ili nisu očuvane.

Od kanina svinje izrađen je jedan nož, od segmenta nepravilnog pravokutnog oblika. Radna ivica korištena za sječenje naglašeno je istrošena. Osim toga, nađeno je i nekoliko otpadaka od proizvodnje, kao što je segment metapodijalne kosti sa započetim longitudinalnim žlijebom, stvorenim kremenim sječivom, ili komad roga s tragovima rezanja. Ovi otpaci svjedoče da su koštane alatke proizvođene unutar naselja.

Još se među badenskim koštanim nalazima mogu spomenuti malobrojni nalazi s lokaliteta JabukaTri Humke kod Pančeva u Banatu. Na ovom nalazištu konstatirani su ostaci badenskog i kostolačkog naselja, dosta uništeni kasnijim korištenjem ovog mjesta prije svega za sahranjivanje (humak kulture grobova u jami, sarmatsko i srednjovjekovno groblje) (Uzelac 2002). Među ostacima badenskog naselja otkriveno je i nekoliko koštanih predmeta: tri koštana dlijeta ili spatule-dlijeta i jedna masivna sjekira ili sjekira-čekić od odbačenog roga jelena s kružnom perforacijom u baznom dijelu (Uzelac 2002: t. 47/5-8).

\section{Kulturni kompleks Bubanj-Sălcuța-Krivodol}

Koštana industrija kompleksa Bubanj-Sălcuța-Krivodol poznata je s eponimnog lokaliteta BubanjNovo Selo, u današnjem predgrađu grada Niša. Obimna istraživanja provedena su u više navrata tijekom 20. stoljeća i otkriven je višeslojni lokalitet s ostacima naselja iz perioda ranoga neolitika
Also should be mentioned one almost completely preserved projectile point. It was made from long bone of a large ruminant (Fig. 2/1). It has full circular cross-section, on its distal end is massive point, while the basal part is fragmented. On the body of the object are visible traces of scraping with a chipped stone tool. Typologically and technologically, it is similar to the projectile points discovered at the site of Gyõr-Szabadrét-Domb.

Among the red deer antler tools, two better preserved can be outlined. The first one is a chisel made from tine, where the natural tine tip is modified into a cutting tool, finely polished and worn from use, probably used in wood working. The other object is massive cutting tool, axe or adze (Fig. $2 / 3$ ). It was made from beam segment. The distal end is obtained by oblique cutting and by scraping and burnishing is formed straight, sharp cutting edge. The basal part is not preserved. The perforations did not exist or were not preserved.

From pig canine one knife was made, from a segment of irregular rectangular shape. The working edge used for cutting is heavily worn. Besides, several pieces of manufacture debris were recovered, such as one metapodial bone with unfinished longitudinal groove, or antler piece with traces of cutting. This manufacturing waste shows that the bone tools were produced within the settlement.

Among the bone artefacts of the Baden culture we can also mention few finds from the site of JabukaTri Humke near Pančevo in Banat. At this site were noted the remains of the Baden and Kostolac culture settlements, heavily destroyed by later use of this location, mainly for burials (tumulus of the Yamnaya culture, necropoles from Sarmatian and Middle Age periods) (Uzelac 2002). Among the remains of the Baden culture settlement few bone artefacts were found: three chisels or spatula-chisels made of bone, and one heavy duty tool, axe or hammer-axe made from shed red deer antler, with circular perforation at the base (Uzelac 2002: t. 47/5-8).

\section{Bubanj-Sălcuța-Krivodol cultural complex}

The bone industry of the cultural complex BubanjSălcuța-Krivodol is known from the eponymous site of Bubanj-Novo Selo, today suburb of the city of Niš. Extensive excavations were carried out in several campaigns during the 20th century and multi-layered site was discovered, with the remains 


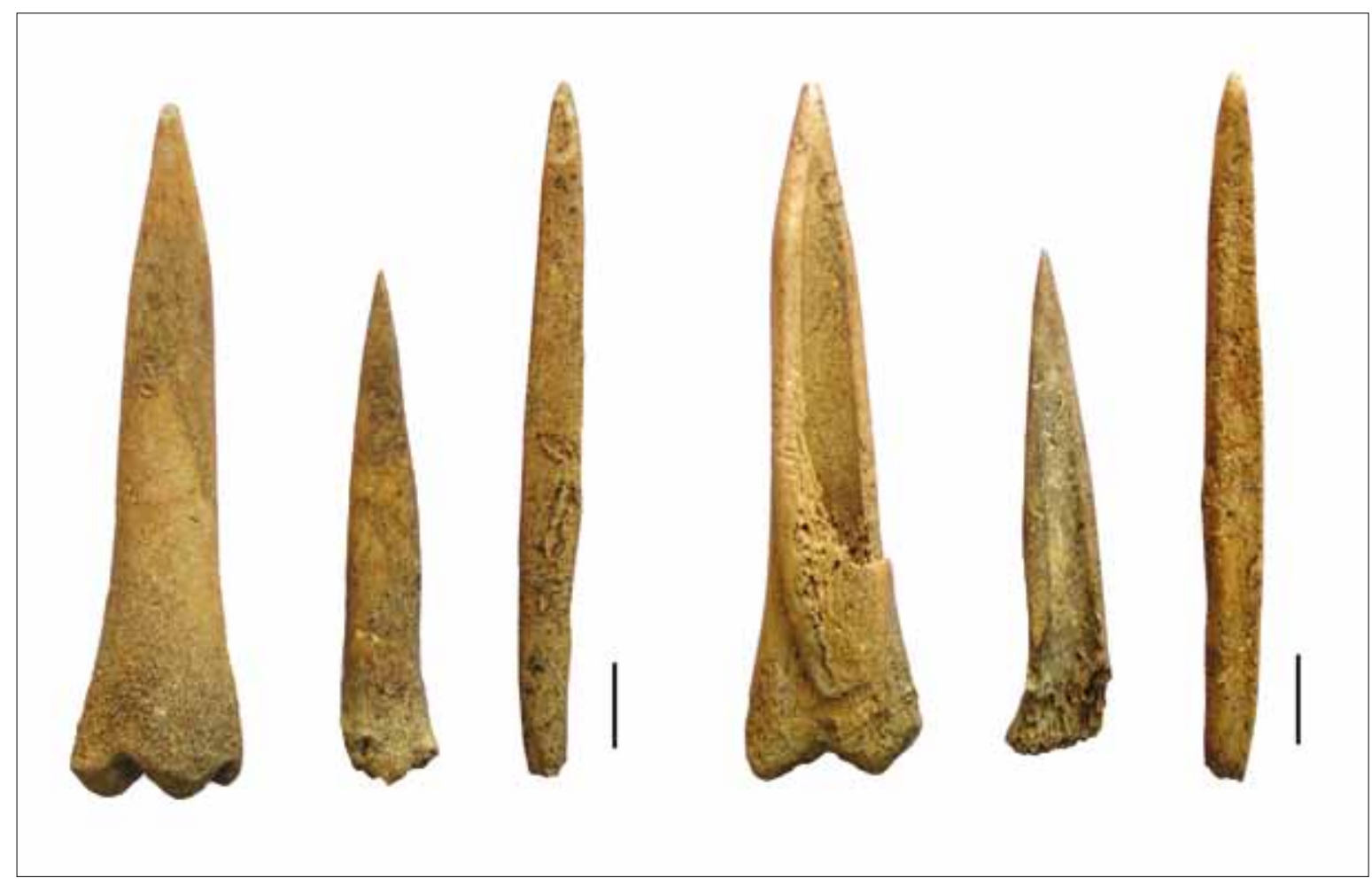

Slika / Figure 3. Različite šiljate alatke, Bubanj-Novo Selo, kulturni kompleks Bubanj-Sălcuța-Krivodol / Diverse pointed tools, Bubanj-Novo Selo, cultural complex Bubanj-Sălcuța-Krivodol (foto / photo: S. Vitezović).

(starčevačka kultura), više eneolitičkih kultura i brončanoga doba, kao i nekropola iz kasnoga srednjeg vijeka (Bulatović \& Milanović 2012; Bulatović et al. 2014, sa referencama). Prikupljena arheološka građa poslužila je za definiranje prapovijesnih kultura u regiji, osobito za definiranje eneolitičke kulture Bubanj-Hum I i brončanodobne kulture Bubanj III (Гарашанин 1973). Izgradnjom željeznice i autoceste, lokalitet je gotovo u potpunosti uništen te su u periodu od 2009. do 2014. godine provedena revizijska istraživanja na malom preostaIom dijelu lokaliteta (Bulatović \& Milanović 2012; Bulatović et al. 2014).

Ovim istraživanjima prikupljeni su bogati faunalni ostaci i njihovim pažljivim pregledom izdvojeno je više od 200 koštanih artefakata (Vitezović, in press). Većina predmeta potječe iz slojeva kulture Bubanj-Hum I, dok manji dio pripada horizontima Kostolac-Coțofeni i Cernavoda III (v. dolje u tekstu). Osim toga, tijekom ranijih istraživanja skupljena je manja količina reprezentativnih koštanih predmeta, uglavnom masivnih artefakata od roga. of settlements from the Early Neolithic (Starčevo culture), several Eneolithic cultures and the Bronze Age, and also necropolis from late Middle Ages (Гарашанин 1973; Bulatović \& Milanović 2012; Bulatović et al. 2014, and references therein). The collected archaeological material was the basis for the defining the prehistoric cultures in the region, in particular for defining the Eneolithic culture Bubanj-Hum I and the Bronze Age culture Bubanj III (Гарашанин 1973). The construction of the railway and motorway destroyed almost completely the site, therefore, in the period between 2008 and 2014 revision archaeological excavations were carried out on the small remaining portion of the site (Bulatović \& Milanović 2012; Bulatović et al. 2014).

During these researches also rich faunal remains were recovered and their careful examination enabled to single out over 200 osseous artefacts (Vitezović, in press). Majority of these items originates from the layers of the Bubanj-Hum I culture, while smaller portion may be attributed to the horizons of the Kostolac-Coțofeni and Cernavoda III cultures (see further down in the text). Besides these, during earlier excavations a smaller quantity of the most attractive bone items was collected, mainly large objects made from antlers. 
Od koštanih sirovina zastupljenih u naselju ranoga eneolitika na Bubnju prisutni su kosti, rogovi cervida, zubi i ljušture mekušaca. U zbirci prikupljenoj tijekom istraživanja 2008-2014 prevladavaju kosti: duge kosti, rebra i rijetko drugi skeletni elementi, uglavnom od domaćih životinja, i to od ovce/koze i goveda, dok se ostale vrste sreću rijetko. Rogovi su razmjerno rijetki i isključivo od jelena, međutim, o važnosti rogova kao sirovine svjedoče nalazi s istraživanja provedenih tijekom 20. stoljeća. Štoviše, ova razlika možda pokazuje da su se drukčije aktivnosti odvijale u onome dijelu naselja gdje su rogovi više nalaženi. Osim toga, prisutni su malobrojni kanini svinje (od čega je najmanje jedan sigurno od divlje svinje). Nađen je svega jedan predmet od importirane morske školjke Spondylus.

Grupa zašiljenih predmeta obuhvaća šila, odnosno srednje jake šiljke, igle ili fine zašiljene alatke i probojce ili masivne šiljke (SI. 3). Šila su najbrojniji tip. Najčešće se izrađuju od metapodijalnih kostiju ovce/koze. Kosti su po dužini cijepane duž žlijeba koji je urezan kremenim sječivom ili dlijetom, a finalno glačanje i poliranje vršeno je abrazivnim kamenim alatom. Neki primjerci imaju epifizu očuvanu na bazi. Uglavnom imaju intenzivnu ispoliranost $\mathrm{i}$ istrošenost od uporabe, što pokazuje da su korišteni uglavnom na mekim, organskim materijalima (cf. Peltier 1986; Maigrot 2003; Christidou \& Legrand 2005; Legrand 2007).

$\mathrm{U}$ grupu alata za sječenje pripada nekoliko predmeta izrađenih od kanina svinje, koji su korišteni kao neka vrsta noževa. Slabo su očuvani; s obzirom na to da su ovi zubi dosta krti, predmeti se često nalaze fragmentirani. Obično su izrađeni od raskoljenih segmenata zuba, manje-više u obliku polumjeseca, i imaju intenzivne tragove uporabe u vidu istrošenih, iskrzanih radnih ivica. Ovoj grupe pripada i jedna fragmentirana alatka od segmenta roga jelena, najvjerojatnije sjekira ili tesla, nađena tijekom istraživanja 2008-14. S ranijih istraživanja potječe nekoliko sjekira, tesli i dlijeta od segmenata rogova, često sa kružnom perforacijom na baznom dijelu.

Od alata za glačanje pronađeno je nekoliko spatula i strugača, uglavnom izrađenih od rebara. Rebra su obično cijepana po dužini pa se alatka izrađuje od jedne koštane pločice, obično manje-više pravokutnog oblika. Na njima su vidljivi i intenzivni tragovi uporabe od kontakta mekim organskim materijalima: istrošene površine, sjaj, ispoliranost
Raw materials used in the Early Eneolithic layers on Bubanj were bones, red deer antlers, teeth and mollusc shells. Within the assemblage collected during the excavations 2008-2014 bones prevail: long bones, ribs and rarely other skeletal elements, mainly from domestic animals, from sheep/goats and cattle, rarely from other species. Antlers are not frequent and only those from red deer were used, however, the importance of antler as raw material is visible in the material collected during the excavations in the $20^{\text {th }}$ century. In fact, this difference perhaps points that different activities were carried out in the parts of the settlement where antlers were more frequently found. Besides these raw materials, there are also few boar tusks (at least one is certainly from wild pig). Just one object made from imported mollusc Spondylus was discovered.

The group of pointed tools includes medium points - awls, fine points - needles and heavy points (Fig. 3). Awls are the most frequent type. The most common are those made from metapodial bones of sheep/goats. Bones were longitudinally split along the groove prepared with the chipped stone burin or blade, and the final burnishing and polishing was done by abrasive stone tools. Some examples have the epiphysis preserved at the base. They usually display heavy polish and worn surfaces from use, suggesting they were used on soft, organic materials (cf. Peltier 1986; Maigrot 2003; Christidou \& Legrand 2005; Legrand 2007).

Several artefacts made from boar tusks can be attributed to the group of cutting tools; they were used as some sort of knives. They are not well preserved; these teeth are brittle and the objects are often fragmented. Usually they were produced from split tusks, they have more-less crescent shape, and their edges are worn. Among the cutting tools also belongs one fragmented tool made from red deer antler, most likely axe or adze, discovered during the excavation campaigns in 2008-14. Previous excavations yielded several axes, adzes and chisels from antler segments, often with a circular perforation on the basal part.

The group of burnishing tools encompass several spatulae and scrapers, made mainly from ribs. Ribs were usually longitudinally split, so the tools were produced from one bone plate of the rib, more-less rectangular in shape. Intensive traces of use are visible on them, result from contact with soft organic materials: worn surfaces, polish, shine and sometimes irregular striations from use (cf. Peltier 1986; 


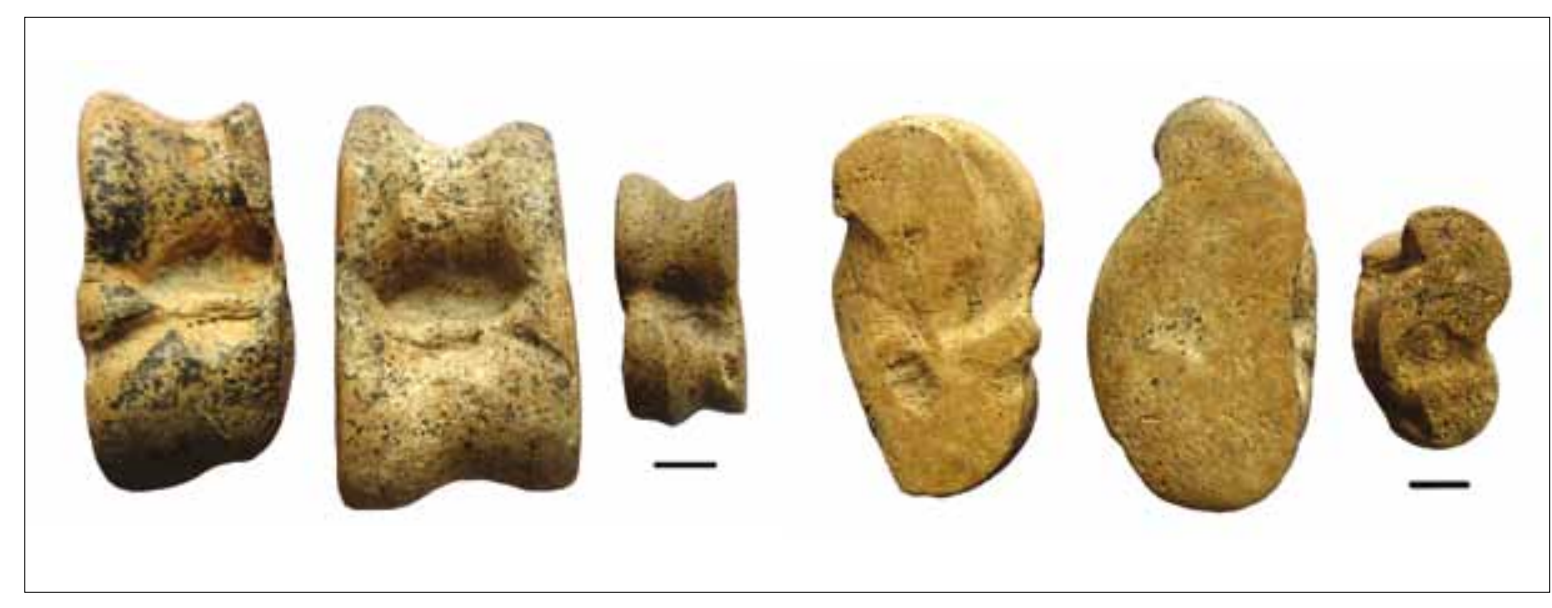

Slika / Figure 4. Modificirani astragali, Bubanj-Novo Selo, kulturni kompleks Bubanj-Sălcuța-Krivodol / Modified astragals, Bubanj-Novo Selo, cultural complex Bubanj-Sălcuța-Krivodol (foto / photo: S. Vitezović).

i ponegdje nepravilne strije od uporabe (cf. Peltier 1986; Maigrot 2003; Christidou \& Legrand 2005; Legrand 2007).

Pronađeno je i nekoliko modificiranih astragala $s$ tragovima upotrebljavanja, od jelena, ovce i svinje (SI. 4). Njihove lateralne stranice u potpunosti su ostrugane nekim abrazivnim sredstvom, a još se mogu uočiti intenzivna ispoliranost, sjaj i guste strije. Njihova namjena, međutim, nije jasna. Eksperimenti na sličnim predmetima koji su pronađeni na nekoliko brončanodobnih lokaliteta u Mađarskoj, pokazuju da su vjerojatno korišteni u radu s glinom (Meier 2013). Tragovi upotrebe na našim primjercima, osobito intenzivna ispoliranost $\mathrm{i}$ sjaj, pokazuju da je vjerojatnije da su korišteni u kontaktu s organskim materijalima, kao što su kože ili biljna vlakna (Peltier 1986; Maigrot 2003; Christidou \& Legrand 2005; Legrand 2007). Da bi se ustanovila njihova funkcija i način korištenja, potrebna su daljnja eksperimentalna istraživanja.

Modificirani astragali, vjerojatno različitih namjena, sreću se u brojnim prapovijesnim kulturama u Europi; između ostalog, u kasno neolitičkoj vinčanskoj kulturi (Vitezović 2007), kao i u eneolitičkim kulturama u Rumunjskoj (e.g., Kogălniceanu et al. 2014) i Bugarskoj (e.g., Zidarov 2005), u brončanom dobu Mađarske (Meier 2013) i tako dalje.

Otkrivena su samo dva ukrasna predmeta su. Jedno je fragmentirana narukvica od morske školjke Spondylus. Ovakve su narukvice dosta česte na brojnim neolitičkim i eneolitičkim lokalitetima u Europi (cf. Borrello \& Micheli 2004; Séfériadès 2010, sa referencama). Drugi artefakt je fragmentirana igla od segmenta duge kosti. Na baznom dijelu
Maigrot 2003; Christidou \& Legrand 2005; Legrand 2007).

Several modified astragals with traces of use were found, from red deer, sheep and pig (Fig. 4). Their lateral surfaces were completely scraped by some abrasive tool, and also intensive polish, shine and dense striations are visible. Their purpose, however, is not clear. Experiments with similar items discovered on several Bronze Age sites in Hungary showed that they were most likely used in processing clay (Meier 2013). The traces of use on our examples, however, especially the intensive polish and shine, show they were most likely used in contact with organic materials, such as leathers or plant fibres (Peltier 1986; Maigrot 2003; Christidou \& Legrand 2005; Legrand 2007). In order to establish their function and the mode of use, further experimental researches are needed.

Modified astragals, probably od different functions, can be encountered among the numerous prehistoric cultures in Europe; among others, in the Late Neolithic Vinča culture (Vitezović 2007), among Eneolithic cultures in Romania (e.g., Kogălniceanu et al. 2014) and Bulgaria (e.g., Zidarov 2005), in the Bronze Age in Hungary (Meier 2013), and so on.

Only two decorative items were discovered. One is fragmented bracelet from the marine Spondylus shell. Similar bracelets are encountered in numerous Neolithic and Eneolithic sites across Europe (cf. Borrello \& Micheli 2004; Séfériadès 2010, and references therein). The other artefact is fragmented pin made from long bone segment,. It has rounded head at the basal part, with perforation, and thin, slender mesial part. The distal portion is fragment- 
ima kružnu glavu s perforacijom i tanko tijelo u mezijalnom dijelu. Distalni dio nedostaje. Cijeli predmet je fino ispoliran. Sama perforacija je naglašeno deformirana intenzivnim korištenjem, a površine su također pokrivene sjajem od manipulacije i upotrebe (cf. Newcomer 1974; d'Errico 1993).

Još jedan značajan lokalitet bubanjske kulture je Lazareva ili Zlotska pećina kod Zlota, $20 \mathrm{~km}$ udaljena od Bora. U periodu između 1963. i 1969. godine istražena je jedna veća galerija, s bogatim ostacima iz eneolitika i željeznoga doba. Radi se o specifičnom lokalitetu koji je korišten vjerojatno samo povremeno, odnosno sezonski. Pretpostavka istraživača je da je to bio metalurški centar, zbog bogatih nalaza bakarnih predmeta, ali i tragova same rude i šljake (Tasić 1995: 172-173).

U okviru horizonta Bubanj-Sălcuța-Krivodol pronađena je razmjerno bogata zbirka koštanih predmeta i to pretežno rogova jelena (Vitezović, u pripremi). Svi segmenti rogova su korišteni - baze, stabla i parošci. Prisutnost većeg broja segmenata s očuvanom bazom pokazuje da se radi o odbačenim rogovima pa se može pretpostaviti da je veći dio ili čak cjelokupna količina sirovine planski prikupljana. Tipološki repertoar nije jako raznovrstan i pretežno se radi o sjekirama, teslama, dlijetima $i$ klinovima. Veliki broj predmeta ima perforaciju na bazi, za uglavljivanje drvenog drška. Sam način izrade je jednostavan, ali dosta standardiziran obično su čeoni parošci uklonjeni sa stabla kombiniranom cut-and-break tehnikom, a radna ivica je dobivana kosim sječenjem. Vanjske površine nisu dodatno dotjerivane, već se raspoznaju prirodne neravnine rogova. Korteks roga obično je stanjivan struganjem prije nego što se napravi perforacija; sama perforacije najčešće je kružnog oblika i obično promjera cca $2 \mathrm{~cm}$. Namjena ovih predmeta vjerojatno je vezana za obradu drva. Moguće je da je to bila jedna od aktivnosti grupa koje su nastanjivale pećinu, ali i da su velike količine drva pribavljane zarad metalurških aktivnosti.

S preostalih bubanjskih nalazišta koštani artefakti su malobrojni ili se uopće ne spominju u izvještajima, odnosno, može se pretpostaviti da se na faunalne ostatke slabo obraćala pažnja i da su samo odabrani koštani predmeti prikupljani. Može se još samo spomenuti jedna dobro očuvana masivna sjekira s ovalnom perforacijom na baznom dijelu koja potječe s lokaliteta Hisar kod Suve Reke na Kosovu (Тасић 1998: 494, kat. 98). ed. The entire object is finely polished. The perforation is heavily deformed from intensive use, and the most of the preserved surfaces are also covered by polish and shine from manipulation and use (cf. Newcomer 1974; d'Errico 1993).

Another important site of the Bubanj culture is the site of Lazareva or Zlotska cave near Zlot, $20 \mathrm{~km}$ from the town of Bor. In the period between 1963 and 1969 one larger room, with rich remains from the Eneolithic and Iron Age. This site had specific character, it was probably used only occasionally, or seasonally. The excavators offered the hypothesis that it was a metallurgical centre, because of rich finds of copper objects, but also because of traces of copper ore and slag (Tasić 1995: 172-173).

Within the horizon of the Bubanj-Sălcuța-Krivodol cultural complex relatively rich assemblage of osseous artefacts was discovered, mainly consisting of red deer antlers (Vitezović, in prep.). All antler segments were used - basal parts, beams and tines. The presence of large quantities of the segments with preserved base show that these were shed antlers; and we may assume that the raw material was mainly or even exclusively obtained by planned collecting. The typological repertoire is not very diverse and includes axes, adzes, chisels and wedges. Many of these objects have the perforation on the base, for the wooden handle. The manufacturing procedure was rather simple, but highly standardized - usually brow tines were removed by combined cut-and-break technique, and the working edge was obtained by oblique cutting Outer surfaces were not additionally modified, and the naturally rough surface of the antler is still visible. The cortex was usually thinned by scraping before the perforation was executed; perforation itself was generally circular in shape and usually its diameter was cca $2 \mathrm{~cm}$. These objects were most likely used in wood-working activities. It is possible that this was one of the activities practiced by groups that inhabited the cave, but perhaps the large quantities of wood were also needed for metallurgical activities.

Bone artefacts from remaining Bubanj culture sites are very few or they are not mentioned at all in the reports, meaning that we may assume that the attention was not paid to the faunal remains and that only selected bone objects were collected. We may only mention one well preserved massive axe with oval perforation on the basal part found at the site of Hisar near Suva Reka on Kosovo (Тасић 1998: 494, kat. 98). 


\section{Koštane figure}

Posebno interesantna novina eneolitičkog perioda u koštanoj industriji jest pojava antropomorfnih figura. Dok su u neolitičkom periodu u jugoistočnoj Europi figure bile gotovo isključivo od gline, s rijetkim primjercima od kamena, sada se javlja nekoliko tipova figura izrađivanih od kostiju.

Tipološku klasifikaciju koštanih figura predložilo je više autora, s manjim varijacijama (cf. Петков 1950: 25-26, sa referencama). Mogu se izdvojiti tri osnovna tipa (SI. 5, 6): 1) shematizovane figure lučnog presjeka s dodatkom, koje se još nazivaju i violinskim, obično nešto većih dimenzija, 2) plosnate figure srednjih dimenzija i 3) figure od kratkih kostiju gdje je prirodni oblik minimalno modificiran i uglavnom ograničen na dodavanje perforacija i struganje površina (cf. Todorova \& Vajsov 2001; Andreescu 2002: 55-67, Manolakakis \& Averbouh 2004; Averbouh \& Zidarov 2014). Plosnate figure uglavnom čine tri dijela - glava, koja može biti trokutasta, ovalna ili heksagonalna; torzo, obično ukrašen; i noge, koje mogu biti samo shematizirane, spojene ili razdvojene i veoma pažljivo izrađene (cf. Петков 1950; Comşa 1979; Andreescu 2002: 55-67). Ponekad, ove figure imaju elemente od drugih materijala, osobito bakra (Todorova \& Vajsov 2001), ali i kamena, kao što je serpentinit (Георгиева 2014).

Plosnate antropomorfne figure čest su nalaz u današnjoj Bugarskoj i Rumunjskoj, u eneolitičkim kulturnim kompleksima Bubanj-Salcuța-Krivodol i Kodjadermen-Gumelnița-Karanovo VI. Štoviše, smatraju se kulturno-kronološki osjetljivim tipom za halkolit istočnoga Balkana ("index fossils", "fossiles directeurs") (cf. Георгиева 2014: 225; Averbouh \& Zidarov 2014: 183). Ove se figure javljaju od faze Gumelnița $A 1$, dosta su uobičajene tijekom faza $A 2$ i B1, i čini se da su nešto češće u ranijim fazama kulturnoga kompleksa Bubanj-SalcuțaKrivodol (cf. Berciu 1961, fig. 157/2; Георгиева 2012: 244-245; cf. i Comşa 1976; Andreescu 2002: 55-67). Dosad su otkrivene na više od 80 lokaliteta u istočnoj Rumnjskoj i Bugarskoj (cf. Andreescu 2002; Comşa 1979; Петков 1950; cf. i Averbouh \& Zidarov 2014, sa referencama). Iscrpnoj listi koju su priredili A. Averbouh i P. Zidarov (2014) mogu se još dodati lokaliteti kao što su Kozareva Mogila (Козарева Могила) (Георгиева 2014) u Bugarskoj i Cuptoare u Banatu u Rumunjskoj (Radu 2002: PI. 100/4).

Tijekom istraživanja 2008.-2014. na lokalitetu Bubanj pronađen je i jedan fragment plosnate antro-

\section{Bone figurines}

Particularly interesting innovation of the Eneolithic period within the bone industry is the appearance of the anthropomorphic figurines. While in the Neolithic period in the South-East Europe figurines were made almost exclusively from clay, with rare examples made of stone, now we have several types of figurines manufactured from bones.

Typological classification of the bone figurines was offered by several authors, with minor variations (cf. Петков 1950: 25-26, and references therein). Three main types may be outlined (Fig. 5, 6): 1) schematized vaulted figurines with appendices, also called violin-shaped, usually of considerable dimensions, 2) medium-sized flat figurines, and 3) figurines made from short bones by minimal alterations to their natural shape, mainly limited to perforations and grinding of surfaces (cf. Todorova \& Vajsov 2001; Andreescu 2002: 55-67, Manolakakis \& Averbouh 2004, Averbouh \& Zidarov 2014). Flat figurines usually have three-partite division - head, that may be triangular, oval or hexagonal, torso, usually decorated, and legs, that may be only schematized, joint or very elaborated and separated (cf. Петков 1950; Comşa 1979; Andreescu 2002: 55-67). Sometimes, these figurines had elements made from other material, in particular copper (Todorova \& Vajsov 2001), but also from stones, such as serpentinite (Георгиева 2014).

Flat anthropomorphic figurines are commonly found in present-day Bulgaria and Romania, within the Eneolithic cultural complexes of Bubanj-SalcuțaKrivodol and Kodjadermen-Gumelnița-Karanovo VI. Furthermore, they are considered to be culturallychronologically sensitive type for the Chalcolithic of the eastern Balkans ("index fossils", "fossiles directeurs") (cf. Георгиева 2014: 225; Averbouh \& Zidarov 2014: 183). These figurines appear in since the phase Gumelnița $A 1$, they are quite frequent during the phases $A 2$ and $B 1$, and it seems they are more commonly found in the earlier phases of the cultural complex of Bubanj-Salcuța-Krivodol (cf. Berciu 1961, fig. 157/2; Георгиева 2012: 244-245; cf. and Comşa 1976; Andreescu 2002: 55-67). Until today, figurines were discovered at over 80 sites in eastern Romania and Bulgaria (cf. Andreescu 2002; Comşa 1979; Петков 1950; cf. and Averbouh \& Zidarov 2014, and references therein). To the extensive list provided by A. Averbouh and P. Zidarov (2014) we may also add sites such as Kozareva Mogila (Козарева Могила) (Георгиева 2014) u Bulgaria and Cuptoare in Banat in Romania (Radu 2002: PI. 100/4). 


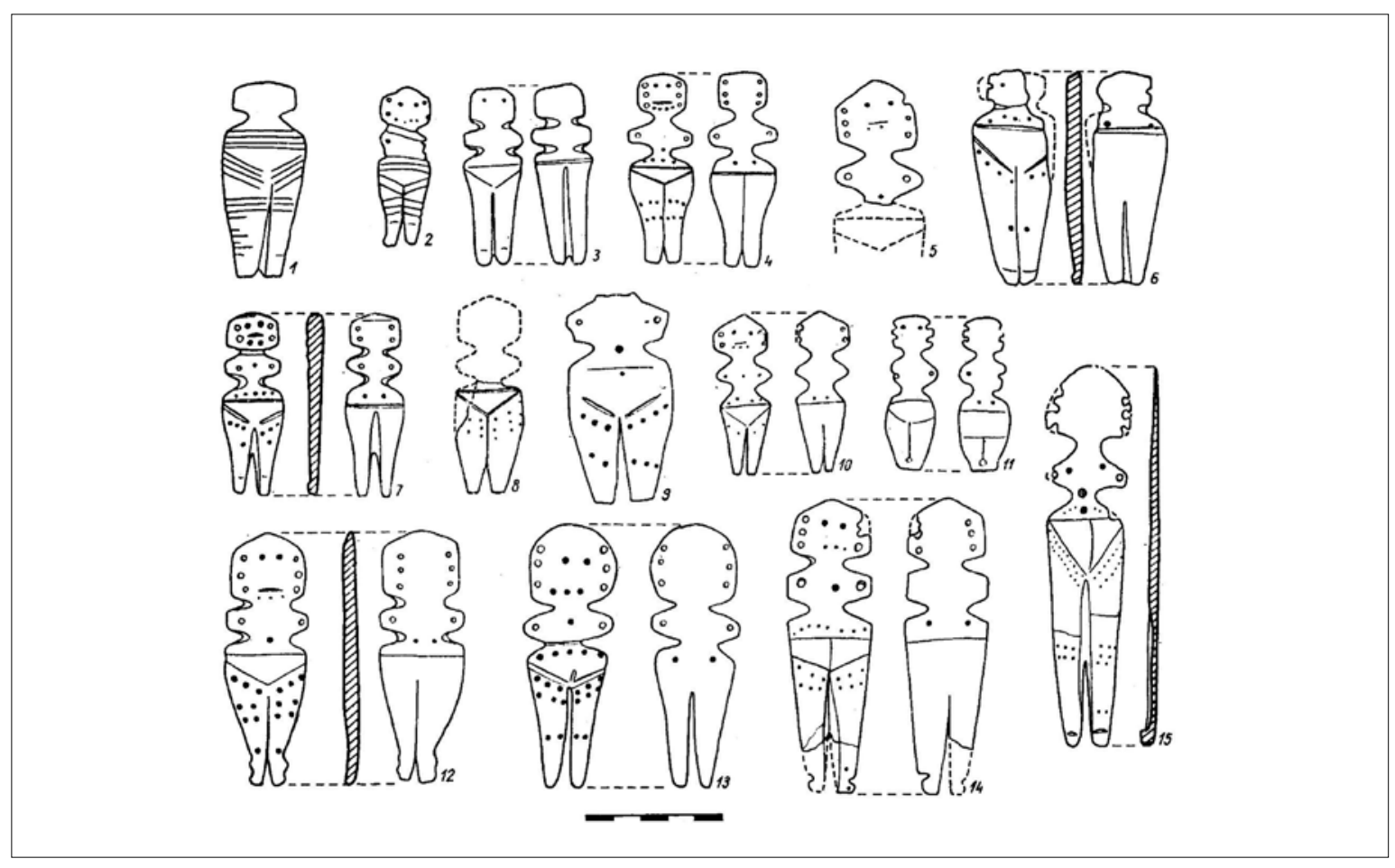

Slika / Figure 5. Koštane figurine iz Rumunjske / Bone figurines from Romania (prema / after: Comşa 1979).

pomorfne figure (Vitezović \& Bulatović 2015). Ovo je prvi i zasad jedini nalaz ove vrste s teritorija Srbije, i istovremeno najzapadniji ovakav nalaz, koji samim tim pokazuje nešto drukčiju sliku o distribuciji ovih figura nego što se ranije smatralo. Od figure je očuvan samo torzo, dok glava i noge nedostaju. Izrađena je od segmenta duge kosti (humerusa ili tibije) srednje krupne životinje. Ukras na njoj se sastoji od tri horizontalna žlijeba, ispod kojih su dva dijagonalna ureza koji formiraju ukras u obliku latiničnog slova $\mathrm{V}$, i ispod toga se nalaze po tri mala kružna udubljenja sa svake strane. Površina figure dosta je istrošena, i upotrebom i postdepozicijskim procesima. Izrađena je sječenjem i glačanjem, urezi su izvedeni kremenom alatkom, a kružni ornamenti svrdlom.

Također je interesantan nalaz s lokaliteta Hotnica (Хотница) u Bugarskoj (Ангелов 1961), gdje je otkriveno nekoliko figura u različitim stupnjevima obrade u okviru jednog objekta. Radi se vjerojatno o radionici ili radioničkom mjestu.

Nalazi plosnatih figura u prvome su redu u okvirima naselja; na lokalitetu Pietrele u Rumunjskoj sve su figure otkrivene unutar kuća; nijedna nije nađena na otvorenom prostoru (Hansen 2011: 120). Jedini nalazi iz grobova potječu s nekropole u Varni, na
During the excavations in 2008-2014 on the site of Bubanj one fragment of a flat anthropomorphic figurine was discovered (Vitezović \& Bulatović 2015). This is the first and for the moment the only such find from the territory of Serbia, and at the same moment the westernmost such find, thus showing somewhat different picture of the distribution than previously thought. Only torso of the figurine is preserved, while the head and legs are missing. It was made from a segment of a long bone (humerus or tibia) of middle-sized animal. Its decoration consists three horizontal grooves, below them are two diagonal incisions, forming the ornament in the shape of the Latin letter $V$ and below it are placed three small circular impression on each side. The surface of the figurine is heavily worn, both from use and post depositional processes. It was made by cutting and burnishing; the grooves and incisions were made by chipped stone tool and the circular ornaments with a bow-drill.

Also interesting is the find from the site of Hotnica (Хотница) in Bulgaria (Ангелов 1961), where several figurines different stages of manufacture were discovered within one dwelling. This was some most likely workshop or working place. 


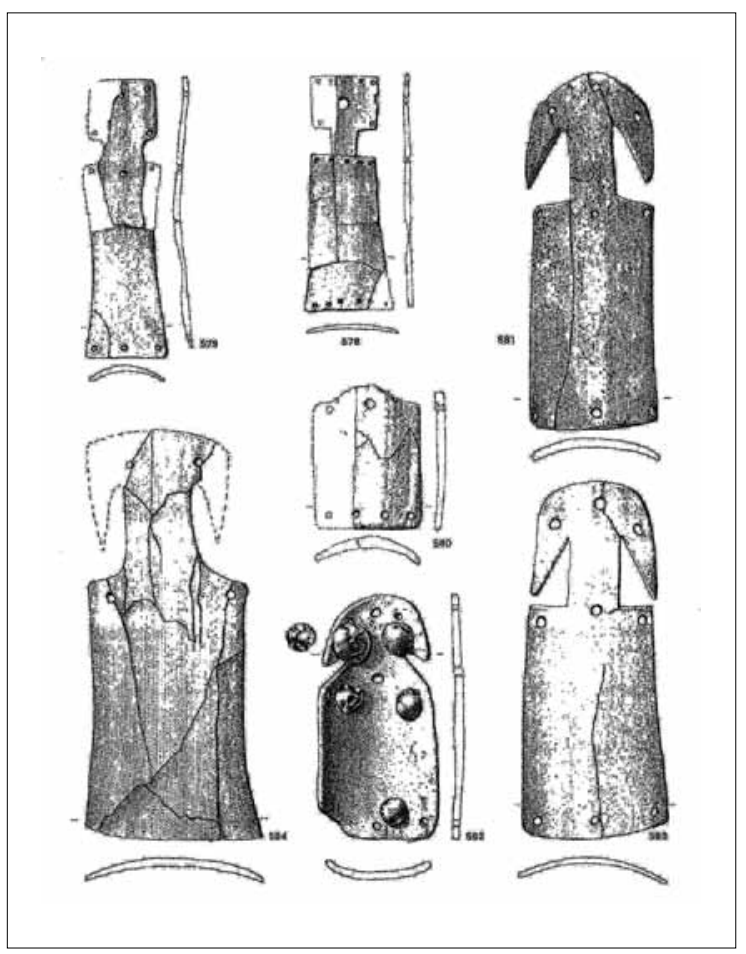

Slika / Figure 6. Koštane figurine iz Varne, Bugarska / Bone figurines from Varna, Bulgaria (prema / after: Todorova \& Vajsov 2001).

obali Crnoga mora. Tu su u većem broju grobova nađene sasvim nove figure, bez tragova manipulacije i korištenja, ukupno 28 primjeraka različitih podtipova (Manolakakis \& Averbouh 2004).

Sve ove figure karakterizira strogi izbor sirovina, ujednačena morfologija i dekoracija (Averbouh \& Zidarov 2014: 183). Prema analitičkom okviru kontinuiteta proizvodnje koji je predložila A. Choyke (1997), figure pripadaju klasi predmeta koji su visoko vrednovani, i u koje je uložen veliki trud, vrijeme i vještina, što im je dalo ili pojačalo prestižni status (cf. Vitezović \& Bulatović 2015). Nastanak i intenzivna proizvodnja ovih figura još je jedan od pokazatelja porasta proizvodnje prestižnih, cijenjenih predmeta (cf. Manolakakis \& Averbouh 2004). Simboličko značenje i prestižni karakter figura vidi se, osim u velikom ulaganju vremena, truda i vještine u izradu, i u tome što su na nekropoli u Varni nađene potpuno nove, nekorištene figure, očito pripremljene upravo u funeralne svrhe. Neki autori također smatraju ove figure "ideološkom inovacijom" ranoga eneolitka (Hansen 2011).

Moguće je da su neke, ako ne i većina ovih figura nošene kao dodatak na odjeći, sudeći po tragovima intenzivnog korištenja koji su uočeni na većini, pa i na figuri s Bubnja (Тодорова 1980; Averbouh \& Zidarov 2014: 191; Vitezović \& Bulatović 2015).
Flat figurines are mainly found within the settlements; at the site of Pietrele in Romania all the figurines were discovered within houses; not a single one was found on an open area (Hansen 2011: 120). The only finds from graves come from the necropolis in Varna, on the Black sea coast. Here numerous graves contained brand new figurines, without any traces of use or manipulation, total of 28 specimen of different figurine subtypes (Manolakakis and Averbouh 2004: 159).

All these figurines are characterized by the strict choice of raw materials, uniform morphology and decorations (Averbouh \& Zidarov 2014: 183). After the conceptual framework of manufacturing continuum, designed by A. Choyke (1997), figurines belong to the class of highly valued objects, with large labour, time and skill investment, that gave and/or increased their prestigious status. (cf. Vitezović \& Bulatović 2015). The occurrence and the intensive production of these figurines is another mark of the increased production of prestigious, valued items (cf. Manolakakis \& Averbouh 2004). The symbolical importance and prestigious character of the figurines is visible, among other, in the high time, labour and skill investment, but also in the fact that on the necropolis in Varna were found brand new, unused figurines, obviously prepared precisely for the funerary purposes. Some authors even consider them as "ideological innovation" of the Early Eneolithic (Hansen 2011).

It is possible that some, if not majority of these figurines were worn attached clothes, judging by the traces of intensive use, visible on most of them, including the figurine from Bubanj (Тодорова 1980; Averbouh \& Zidarov 2014: 191; Vitezović \& Bulatović 2015). 


\section{Kulture Kostolac i Kostolac-Coțofeni}

Nešto podataka o koštanim industrijama u kostolačkoj kulturi imamo s lokaliteta Bubanj kod Niša (v. gore), gdje se javlja lokalna varijanta KostolacCoțofeni (Vitezović, in press).

U koštanoj industriji otkrivenoj tijekom istraživanja 2008.-2014. najzastupljenije su kosti, slijede rogovi jelena, dok ljušture školjki nisu otkrivene. Grupa zašiljenih predmeta obuhvaća uglavnom srednje i masivne šiljke. Srednji šiljci, odnosno šila uglavnom su izrađivani od dugih kostiju sitnijih preživača, kao što su metapodijalne kosti ovce/ koze. Na ovim se šilima mogu uočaiti ispoliranost i istrošenost od upotrebe, što pokazuje da su korišteni uglavnom na mekim, organskim materijalima. Nađen je i manji broj masivnih probojaca.

U grupu alatki za sječenje pripadaju dva masivnija predmeta od roga jelena. Jedno je gotovo cijela sjekira ili tesla, izrađena od baze i segmenta stabla otpalog roga, s perforacijom u baznom dijelu, promjera 1,2 cm (SI. 7). Radna ivica je dobivena kosim zasijecanjem stabla roga i samo je djelomično očuvana. Drugi predmet je dosta fragmentiran, ali se može pretpostaviti da je morfološki i funkcionalno bio dosta sličan prvom.

Grupa alata za glačanje obuhvaća različite spatule, strugače i spatule-dlijeta, od različitih kostiju. Većina spatula i strugača izrađena je od minimalno modificiranih rebara, dok se po pažljivoj izradi

Slika / Figure 7. Sjekira ili tesla od roga jelena, Bubanj-Novo Selo, kultura Kostolac-Coțofeni / Axe or adze from red deer antler, BubanjNovo Selo, culture Kostolac-Coțofeni (foto / photo: S. Vitezović).

\section{Culture Kostolac and Kostolac-Coțofeni}

Some information about the bone industries within the Kostolac culture we have from the site of Bubanj near Niš (see above), where the local variant of Kostolac-Coțofeni was present (Vitezović, in press).

Within the bone industry recovered during the excavations in 2008-2014 the most common raw material were bones, followed by red deer antlers, while mollusc shells were not found. The group of pointed tools encompasses mainly medium and heavy points. Medium points, i.e., awls were usually manufactured from long bones of small ruminants, such as metapodial bones of sheep/goats. On these awls are visible polish and worn surfaces from use, showing they were mainly used on soft, organic materials. Also a small number of heavy points was discovered.

In the group of cutting tools fall two massive objects from red deer antler. One is almost completely preserved axe or adze, made from base and beam segment of a shed antler, with a perforation in the basal part, diameter $1,2 \mathrm{~cm}$ (Fig. 7). Working edge is obtained by oblique cutting of the beam and is only partially preserved. The other objects is heavily fragmented, but we may assume that it was morphologically and functionally very similar to the first one.

The group of burnishing tools includes diverse spatulae, scrapers and spatula-chisels, made from different bones. Majority of spatulae is made from
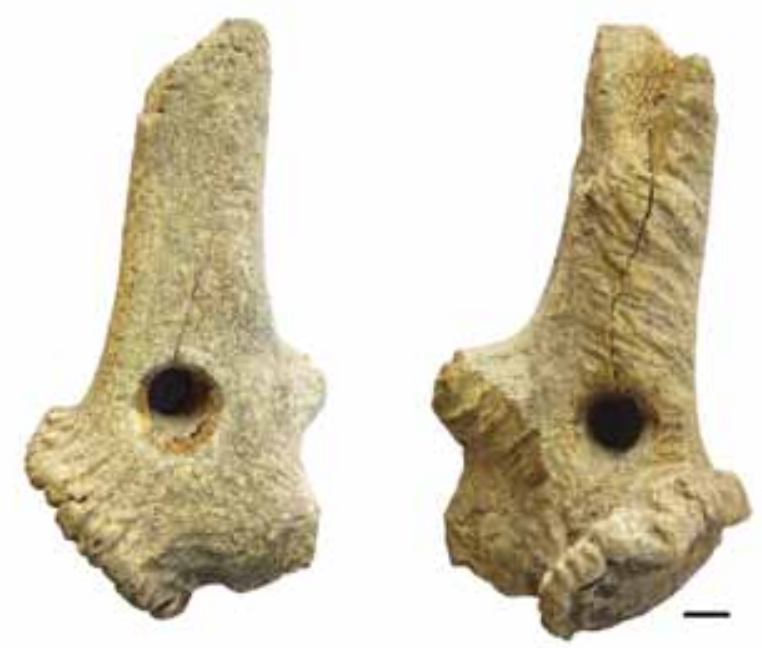


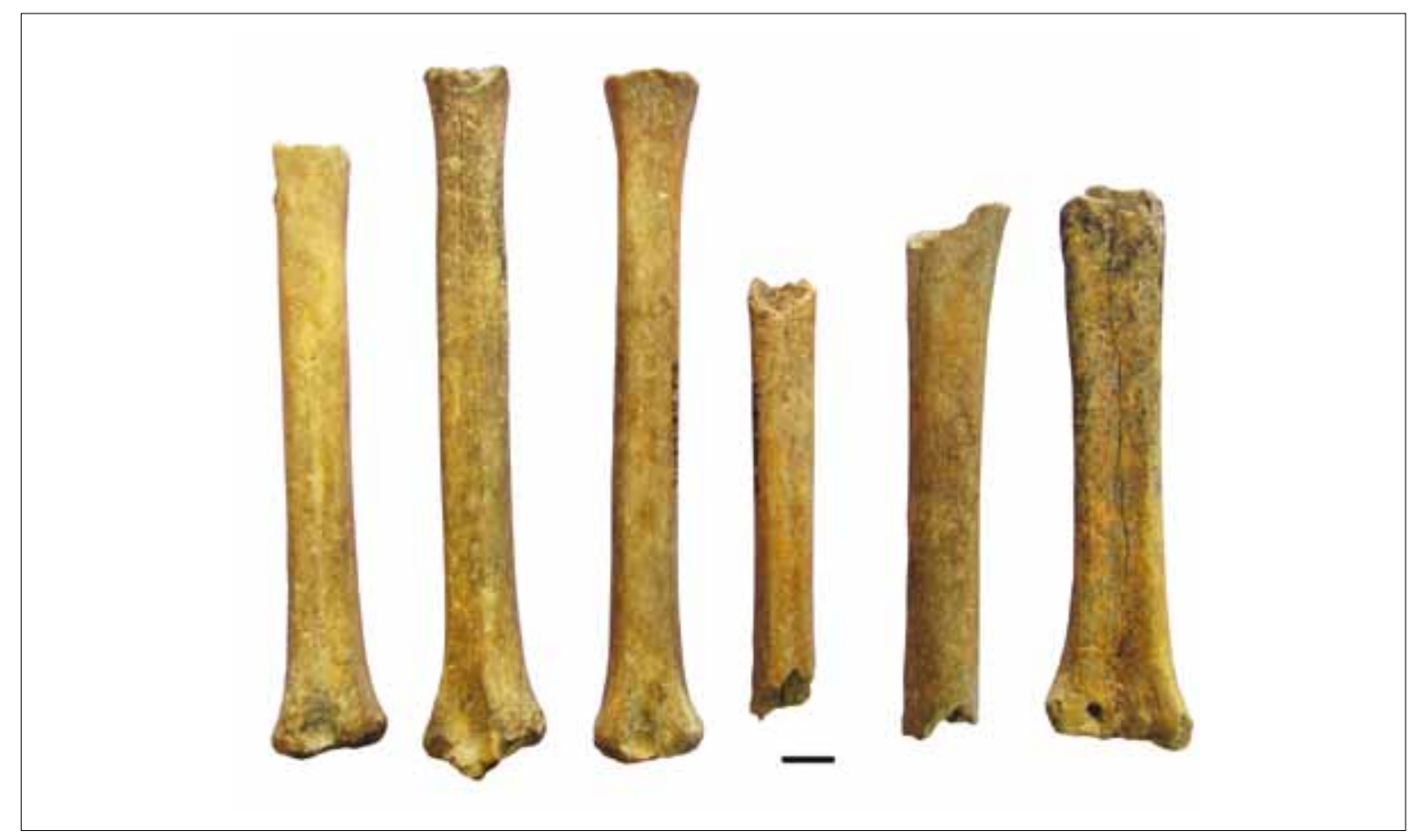

Slika / Figure 8. Koštane drške, Bubanj-Novo-Selo, kultura Kostolac-Coțofeni / Bone handles, Bubanj-Novo Selo, culture Kostolac-Coțofeni (foto / photo: S. Vitezović).

posebno izdvaja spatula-dlijeto od gotovo cijele tibije ovce/koze. Tragovi uporabe i na ovim predmetima pokazuju da su korišteni uglavnom na mekim, organskim materijalima, vjerojatno najviše za obradu kože (Peltier 1986; Maigrot 2003; Christidou \& Legrand 2005; Legrand 2007). Osim toga nađene su dvije mandibule s tragovima korištenja, čija je namjena bila za izradu remenja i drugih predmeta od kože (thong stretcher / thong smoother).

Posebno interesantnu grupu predmeta čini nekoliko držaka (SI. 8). Svi su izrađeni od gotovo cijelih metapodijalnih kostiju ovce/koze. Modificirani su jednostavnim uklanjanjem distalne epifize, a na nekim predmetima se mogu raspoznati i tragovi kako je presječena ivica uglačana abrazivnim kamenim alatom, moguće pješčenjakom. Prirodna šupljina duge kosti iskorištena je za usađivanje nekog drugog predmeta, oštrog i tankog. Tragovi upotrebe sastoje se od ispoliranosti, sjaja i strija bez pravilnog rasporeda, koji su trag manipuliranja i kontakta s materijalom koji je usađeni predmet obrađivao (cf. Barge-Mahieu 1990; d'Errico 1993). Slični tragovi upotrebe uočeni su i na finim, cilindričnim šupljim predmetima, kakvi su otkriveni u eneolitiku Francuske, i koji su identificirani kao dršci nakon što je otkriveno nekoliko primjeraka s još uvijek uglavljenom alatkom (Barge-Mahieu 1990). minimally modified ribs, while one spatula-chisel from almost complete sheep/goat tibia stands out by its careful manufacture. Use wear traces on these objects also show they were predominantly used on soft, organic materials, probably mainly for leather processing (Peltier 1986; Maigrot 2003; Christidou \& Legrand 2005; Legrand 2007). Apart from these, also two mandibles with traces of use were discovered, used in the process of making thongs and other leather items (thong stretcher / thong smoother).

Particularly interesting group of artefacts are several handles (Fig. 8). They were all made from almost complete metapodial bones of sheep/goats. They were modified by removing the distal epiphysis, and on some of them on the cut edge are visible traces of burnishing with abrasive stone, possibly sandstone. The natural cavity of the long bone was used for inserting another object, pointed and slender. Traces of use consist of polish, shine and irregular striations, which are traces of manipulation and contact with the material that was worked by the inserted tool (cf. Barge-Mahieu 1990; d'Errico 1993). Similar traces of use were noted on fine, cylindrical hollow objects, discovered in the Eneolithic in France, which were identified as handles after the discovery of several specimens with still inserted tool (Barge-Mahieu 1990). 
Promjer otvora držaka s Bubnja je prilično malen obično oko 6-8 mm, i najizvjesnija je pretpostavka da su bili namijenjeni bakrenim iglama i šilima, mada su nalazi bakrenih predmeta na Bubnju izuzetno rijetki. Slične dršci, točnije minimalno modificirani segmenti dijafiza dugih kostiju sitnih preživača, s još uvijek uglavljenom bakrenom alatkom poznati su s većeg broja lokaliteta u Europi. Kao jedan od primjera može se spomenuti Azmaška Mogila (Азмашка Могила) u istočnoj Bugarskoj (Калчев 2005: 13).

S drugih kostolačkih lokaliteta koštani predmeti su gotovo potpuno nepoznati. Može se još samo spomenuti jedan držak od duge kosti (vjerojatno metapodijalna kost ovce/koze) s još uvijek uglavIjenim bakrenim šilom, koja je otkrivena na lokalitetu Hisar kod Suve Reke na Kosovu i najvjerojatnije pripada kostolačkom horizontu (Тасић 1998: 500, kat. 108).

\section{Cernavoda kultura}

Koštana artefakta Cernavoda I kulture poznata su nam s lokaliteta Săveni-La Movile u Rumunjskoj, gdje je prikupljena manja zbirka od 50 artefakata (Cernea et al. 2014). Uglavnom su korišteni rogovi. Svega 14 predmeta izrađeno je od kostiju; većinom su zastupljeni različiti šiljci od dugih kostiju. Osim toga, tri različite duge kosti krupnih preživača (metakarpus, metatarzus i radius) iskorištene su kao neka vrsta čekića. Nađena je i jedna alatka za preradu remenja od kože (thong stretcher / thong smoother) od mandibule. Od rogova su izrađivana dlijeta i sjekire; jedan fragmentirani artefakt od baze odbačenog roga i stabla s perforacijom moguće je služio kao sjekira-čekić. Ostaci od proizvodnje razmjerno su brojni, jedan polufabrikat i 18 komada koji predstavljaju otpadak.

Nađena su i dva ukrasna predmeta; privjesak od dijafize duge kosti krupnije životinje i duguljasta cilindrična perla od metapodijalne kosti od životinje vrste Canis/ Vulpes / Lupus. Privjesak je ovalne forme i ima dvije perforacije u gornjem dijelu; jedna je prelomljena i moguće da je druga i izrađena nakon loma prve. Ovaj je predmet najvjerojatnije imitacija takozvanih Gumelnița idola, zlatnih privjesaka kakvi su nađeni na lokalitetu Sultana-Malu Roșu (Cernea et al. 2014: fig. 7).
The diameter of the opening of the handles from Bubanj is quite small, usually about $6-8 \mathrm{~mm}$, and the most plausible hypothesis is that they were intended for copper needles and awls, although copper finds were extremely rare on Bubanj. Similar handles, namely, minimally modified segments of diapyhses of small ruminant long bones, with a copper tool still embedded inside, are known from numerous sites in Europe. As one of the examples we may outline the site of Azmashka Mogila (Азмашка Могила) in eastern Bulgaria (Калчев 2005 13).

From other Kostolac culture sites bone artefacts are almost completely unknown. We may mention here only one handle made from long bone seg ment (probably metapodial bone of sheep/goat) with still inserted copper awl, discovered at the site of Hisar near Suva Reka on Kosovo, which most likely belongs to the Kostolac horizon (Тасић 1998 500, kat. 108).

\section{Cernavoda culture}

Bone artefacts of the Cernavoda I culture were are available from the site of Săveni-La Movile in Romania, where a smaller assemblage of 50 artefacts was collected (Cernea et al. 2014). The predominant raw material were antlers. Only 14 objects were made from bones; mainly diverse points from long bone segments. Also, three different bones from large ruminant (metacarpus, metatarsus and radius) were used as some sort of hammer. One tool made from mandible was found, used in leather working (thong stretcher / thong smoother). Antlers were used to produce chisels and axes; one fragmented tool made from the basal part of the shed antler probably used as a hammer-axe. Manufacture debris is relatively frequent, and include one semifinished item and 18 pieces representing waste.

Two decorative items were discovered; pendant from diaphysis of a long bone from large mammal and one cylindrical bead made from metapodial bone of the animal from species Canis/ Vulpes / Lepus. The pendant has oval shape and two perforations in the upper part; one is broken and it is possible that the second was made after the first one was broken. This objects is most likely imitating the so-called Gumelnița idols, golden pendants found at the site of Sultana-Malu Roşu (Cernea et al. 2014: fig. 7). 

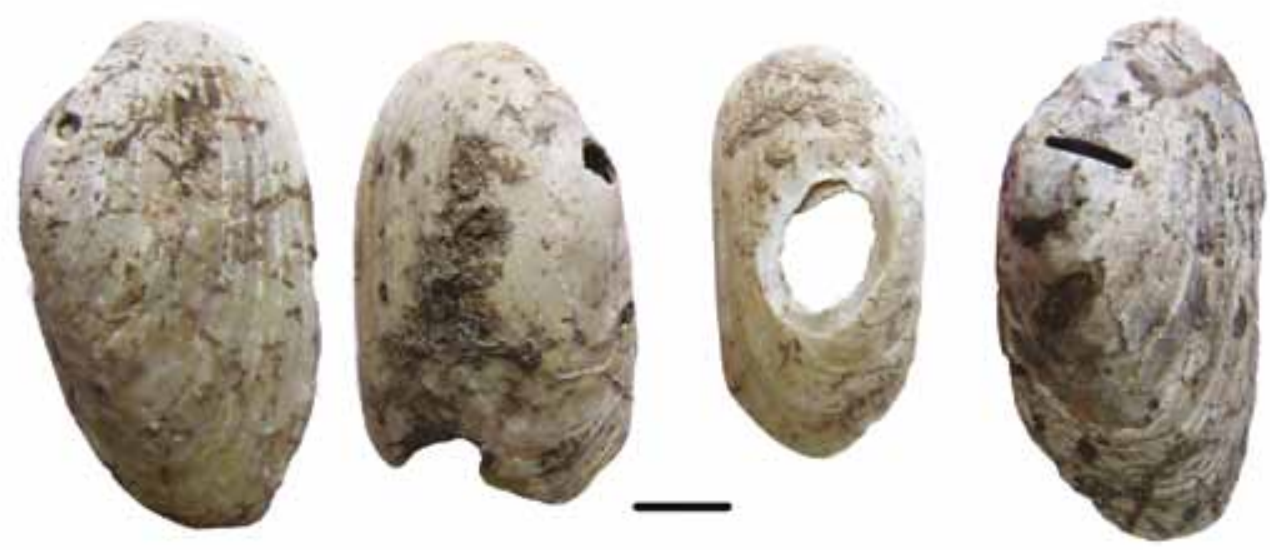

Slika / Figure 9. Ukrasi od Unio školjki, Bubanj-Novo Selo, kultura Cernavoda III / Decorations from Unio shells, Bubanj-Novo Selo, culture Cernavoda III (foto / photo: S. Vitezović).

S lokaliteta Bubanj tijekom istraživanja 2008-2014 manji broj koštanih predmeta otkriven je u okviru horizonta Cernavoda III kulture. Osnovna sirovina su kosti; rogovi nisu otkriveni, ali je pronađeno i nekoliko artefakata izdrađenih od ljuštura riječnih školjki Unio sp.

Najzastupljenija su šila od dugih kostiju sitnih preživača, uglavnom metapodijalnih kostiju ovce/ koze. Kosti su cijepane po dužini, dotjerivane glačanjem, i predmeti često imaju očuvanu epifizu na bazi. Tragovi uporabe, uglačanost, ispoliranost i sjaj, pokazuju da su korištena na mekim, organskim materijalima - za obradu kože i/ili biljnih vlakana (Peltier 1986; Maigrot 2003; Christidou \&Legrand 2005; Legrand 2007). Nekoliko fragmentiranih predmeta od dugih kostiju predstavljaju probojce.

Od alatki za sječenje nađeno je nekoliko artefakata izrađenih od kanina svinje, koji su korišteni kao neka vrsta noževa. U grupi alata za glačanje javljaju se spatule i strugači, izrađivani uglavnom od rebara, i to kako cijepanih po dužini (predmeti od jedne koštane pločice), tako i cijelih (od segmenata rebara pune debljine). Većinom pokazuju vrlo visok intenzitet istrošenosti od upotrebe, od kontakta s mekim, organskim materijalima, te se može pretpostaviti da su najviše korišteni za obradu kože (Peltier 1986; Maigrot 2003).

Modificirani astragali javljaju se i u horizontima Cernavoda. Tragovi korištenja uglavnom su smješteni na condylusima. Jedan astragal ovce/koze ima nedovršenu perforaciju. Za njih možemo pret-
A small number of bone objects was discovered at the site of Bubanj during the excavations in 20082014 within the horizon of Cernavoda III culture. The main raw material were bones; antlers were not noted, but several artefacts made from river Unio sp. shells were discovered.

The most common are awls made from long bones of small ruminants, mainly metapodial bones of sheep/goat. Bones were longitudinally split, finished by burnishing, and these objects often have preserved epiphysis on the base. Use wear traces, smooth surfaces, polish and shine, show these items were used on soft, organic materials - for processing leather and/or plant fibres (Peltier 1986; Maigrot 2003; Christidou \& Legrand 2005; Legrand 2007). Several fragmented tools made from long bones were probably heavy points .

Cutting tools include several items made from boar tusks, used as some sort of knife. The group of burnishing tools include spatulae and scrapers, made mainly from ribs, both split (objects produced on one bone plate), and unsplit (from segments which preserved the full thickness of the bone). They display very intensive use wear, result of the contact with soft, organic materials, and we may assume they were used in leather working (Peltier 1986; Maigrot 2003).

Modified astragals also occur within the Cernavoda horizon. The traces of use on them are mainly located on the condyli. One sheep/goat astragal has unfinished perforation. We may assume that these items had similar function as those from the Early 
postaviti sličnu funkciju kao i za one iz ranoga eneolitika - da su korišteni u obradi mekih organskih materijala, kao što su kože i biljna vlakna, ali su potrebna daljnja istraživanja za preciznije definiranje njihove namjene.

Nađeno je i nekoliko ukrasnih predmeta od riječnih školjki Unio (SI. 9). Pronađeno je nekoliko cijelih valvi sa perforacijama, ali i nekoliko nedovršenih primjeraka - cijele valve s tragovima abrazije i nedovršenim perforacijama. Ovi su ukrasi vjerojatno bili dio ogrlice, ili našiveni na odjeću. Zanimljivo je da su školjke Unio znatno češće korištene u odnosu na neolitički period, i sreću se i na drugim eneolitičkim lokalitetima u jugoistočno Europi. Na lokalitetu kulture Gumelnița tell Hârşova u Rumunjskoj, na primjer, nađena je veća količina cijelih perforiranih valvi, finih perli izrađenih od ove školjke, kao i nedovršeni primjerci (Mărgărit 2008).

\section{Vučedolska kultura}

Mada vučedolska kultura ima dugu tradiciju proučavanja i istražen je veliki broj lokaliteta na velikoj površini, koštana industrija ostala je zanemarena pored ostalih spektakularnih nalaza i nije detaljno analizirana. Poseban problem predstavlja nepotpuna dokumentacija o stratigrafiji nekoliko velikih vučedolskih tell-naselja, s kojih potječe izuzetno veliki broj koštanih predmeta, kao što su sam Vučedol, Sarvaš-Gradac, ili Zók.

Istraživanjima koja su provedena na eponimnom lokalitetu Vučedol u prvoj polovici 20. stoljeća prikupljena je velika količina koštanih predmeta koji se danas čuvaju u Arheološkom muzeju u Zagrebu (Krištofić 2017). U zbirci se nalaze uglavnom masivne alatke od roga, sjekire, tesle, dlijeta, kombinirani perkuteri, kao i otpaci od proizvodnje. Kosti su slabije zastupljene; korištene su uglavnom za igle, šila i različite predmete za glačanje.

S lokaliteta Sarvaš-Gradac u Arheološkom muzeju u Osijeku danas se čuva veća količina predmeta (oko stotinjak) od koštanih sirovina, uglavnom od rogova jelena (Vitezović, u pripremi). Radi se o raznim segmentima - baznim, dijelovima stabla i parošcima. Veći broj rogova s očuvanom bazom pokazuje da se do sirovine dolazilo prije svega prikupljanjem odbačenih rogova, vjerojatno sustavnim i planiranim, ali je manja količina nabavljena ilovom.
Eneolithic layers - they were most likely used in processing soft, organic materials, such as leathers and plant fibres; however, further studies are needed for more precise definition of their purpose.

Several decorative items from river Unio shells were discovered (Fig. 9). Several complete valves with perforations were found, but also several unfinished pieces - complete valves with traces of abrasion and unfinished perforations. These decorations were probably part of the necklace or were attached to the clothes. It is interesting to note that Unio shells are now more common than in the Neolithic period, and they are encountered on other Eneolithic sites in the south-east Europe. On the site of Gumelnița culture Hârşova tell in Romania, for example, a large quantity of complete perforated valves was found, along with fine beads from this shell and several unfinished pieces (Mărgărit 2008).

\section{Vučedol culture}

Although Vučedol culture has long tradition of research and numerous sites on extensive area were investigated, the bone industry remained unnoticed next to the other spectacular finds and was never analysed in detail. In particular, the problem poses the incomplete documentation regarding stratigraphy regarding several large Vučedol tellsettlements, from which extraordinary large number of bone artefacts was uncovered, such as the eponymous site of Vučedol, site of Sarvaš-Gradac, or Zók.

The researches carried out on the eponymous site of Vučedol in the first half of the 2oth century a large quantity of bone objects was collected, today stored at the Archaeological museum in Zagreb (Krištofić 2017). The assemblage consists of mainly massive antler tools, axes, adzes, chisels, combined percussion tools, as well as manufacture debris. Bones were less common; used mainly for needles, awls and diverse burnishing tools.

From the site of Sarvaš-Gradac in the Archaeological museum in Osijek today is stored a larger amount of objects (about one hundred) from osseous raw materials, mainly from red deer antlers (Vitezović, in prep.). Diverse segments are present - bases, beams and tines. Large amount of antlers with preserved base show that the raw material was obtained predominantly by collecting the shed antlers, probably in a systematic and planned way, but a smaller quantities were obtained by hunting. 


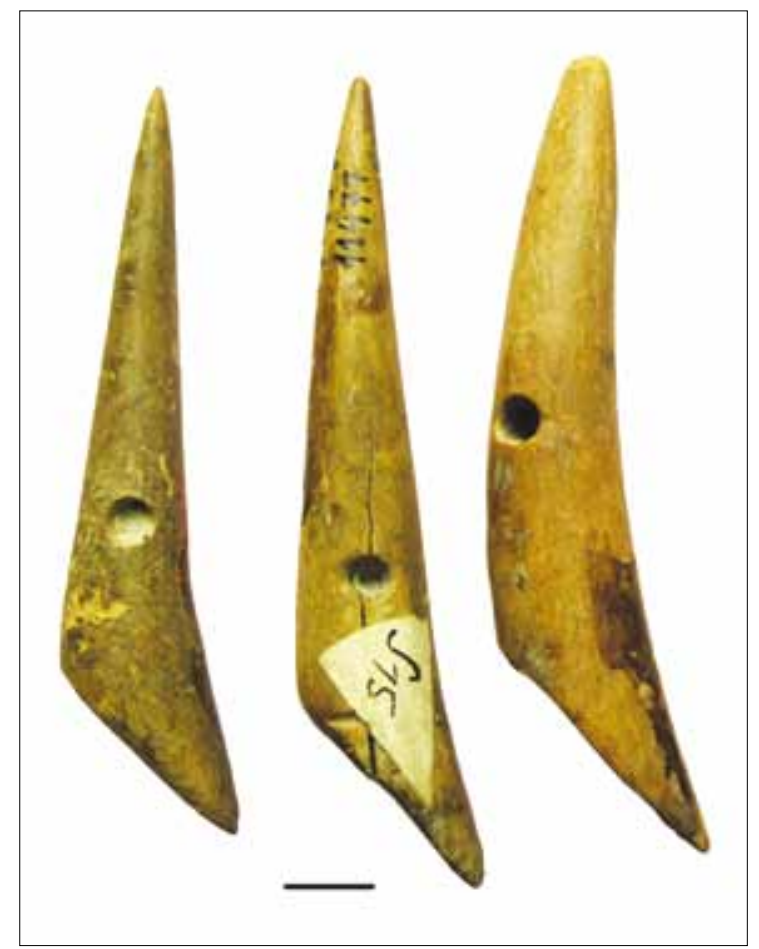

Slika / Figure 10. Konusni harpuni od roga, Sarvaš-Gradac, vučedoIska kultura / Toggle harpoons from antler, Sarvaš-Gradac, Vučedol culture (foto / photo: S. Vitezović).

Tipološki, obuhvaćaju uglavnom masivne alatke za udaranje i sječenje - čekiće, kombinirane perkutere, sjekire, tesle, dlijeta. Često imaju kružnu (rijetko četvrtastu) perforaciju za drveni držak. Među fino izrađenim predmetima osobito se izdvajaju tri cijela, dobro očuvana konusna harpuna (SI. 10). Izrađeni su od manjih parožaka rogova; bazni dijelovi su ukoso isječeni, na mezijalnom dijelu imaju manju perforaciju, dok su sami vrhovi prirodni vršci parožaka dodatno dotjerani struganjem i sječenjem da budu oštriji. Također se u zbirci nalazi i jedan polufabrikat za konusne harpune.

Osim toga, u Muzeju se danas čuva i određena količina otpadaka od proizvodnje - različiti segmenti roga (bazni dijelovi, stabla, parošci) s tragovima cijepanja, piljenja, započetih perforacija, i drugo (SI. $11)$.

Posebno je interesantan lokalitet Zók kod Pečuha u Mađarskoj. Na ovom su lokalitetu provedena istraživanja velikog obujma 1920. godine, i prikupljena je izuzetno velika količina materijala, danas u Narodnom muzeju u Beogradu (Mitrović \& Vitezović 2017). Između ostalog, tu pripada više od 200 koštanih predmeta koji se mogu opredijeliti u kasno-vučedolski i vinkovački horizont (Mitrović \& Vitezović, u pripremi).
Typologically, they encompass mainly massive percussion and cutting tools - hammers, combined percussion tools, axes, adzes, chisels. They often have circular (rarely rectangular) perforation for a wooden handle. Among the finely manufactured items especially stand out three complete, well preserved toggle harpoons (Fig. 10). They were made from smaller tines; their basal parts were obliquely cut, on the mesial part have smaller perforation, while the tips were natural tips of the tine, additionally modified by scraping and burnishing to be sharper. Also in this assemblage is encountered one semi-finished toggle harpoon.

Furthermore, in the Museum is today stored a certain amount of the manufacture debris - different segments of antlers (basal parts, beams, tines) with traces of cutting, sawing, unfinished perforations, etc. (Fig. 11).

Particularly interesting is the site of Zók near Pécs in Hungary. On this site large scale excavation were carried out in 1920, and a very large quantity of the material was collected, today stored in the National museum in Belgrade (Mitrović \& Vitezović 2017). Among others, there is over 200 bone objects that can be attributed to the Late-Vučedol or Vinkovci culture horizon (Mitrović \& Vitezović, in prep.).

Slika / Figure 11. Otpadak ili polufabrikat od roga, Sarvaš-Gradac, vučedolska kultura / Manufacture debris or semifinished item from antler, Sarvaš-Gradac, Vučedol culture (foto / photo: S. Vitezović).

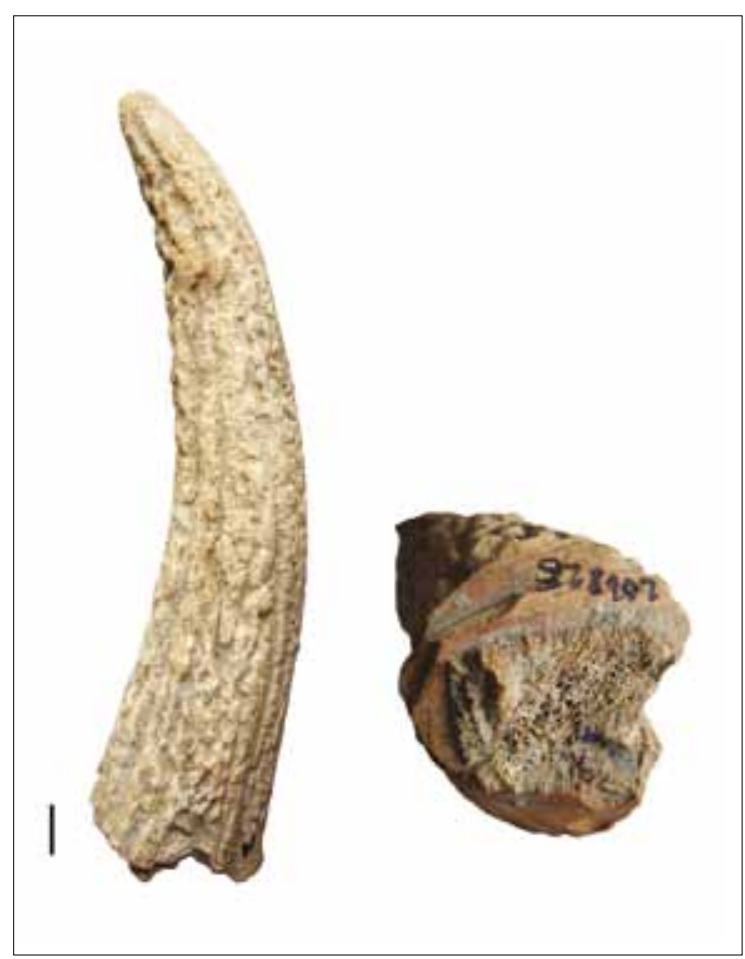



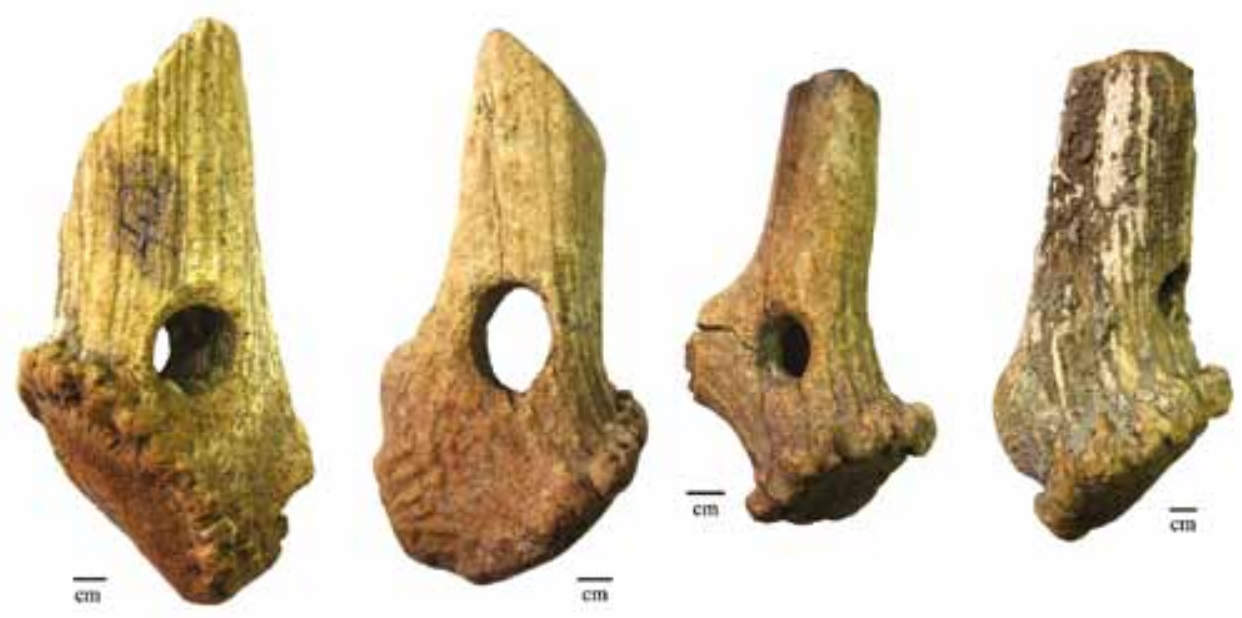

Slika / Figure 12. Sjekire i čekići-sjekire od roga, Zók, vučedolska kultura / Axes and hammer-axes from antler, Zók, Vučedol culture (foto / photo: S. Vitezović).

Slično kao i na Sarvašu, pa i na samom Vučedolu, primjetna je izuzetno velika količina rogova. Radi se uglavnom o rogovima jelena, s rijetkim primjercima rogova srndaća, i zastupljeni su svi segmenti - bazni dijelovi, stabla, parošci. Veliki dio predstavljaju odbačeni rogovi, ali i ovdje je prisutna manja količina rogova od ubijenih životinja. Tipološki repertoar obuhvaća masivne alatke za sječenje i perkutere - sjekire, tesle, dlijeta, klinove, kombinare sjekire-čekiće, obične čekiće, manje perkutere i drugo (SI. 12). Znatna je količina i otpada od proizvodnje - bazni dijelovi, segmenti stabla i parošci s tragovima rezanja, piljenja, započetim perforacijama, i drugo. Ovako velika količina svakako ukazuje na vrlo intenzivnu proizvodnju. Posebno značajna odlika industrije roga i sa Sarvaša i sa Zóka jesu tragovi obrade metalnim alatom (cf. Christidou 2008).

Predmeti od kostiju obuhvaćaju jednostavne oblike srednjih, finih i masivnih šiljaka od različitih dugih kostiju (uglavnom metapodijalnih, tibija i rebara) sitnih i krupnih preživača, kao i spatule i strugače od rebara i dlijeta od cijepanih dugih kostiju.

Kanini svinje, i domaće i divlje, dosta su korišteni za izradu predmeta. Dio njih predstavljaju razne oblike strugača, međutim, dosta su loše očuvani i za veliki dio nije moguće rekonstuirati prvotni izgled i namjenu.

Još se među predmetima od roga osobito izdvaja nekoliko konusnih harpuna, vrlo fine izrade. Konusni harpuni od rogova mogu se smatrati karakte-
The situation is similar as in Sarvaš and Vučedol - the amount of antlers is very high. These were mainly red deer antlers, with rare examples of roe deer, and all the segments are present - basal parts, beams, tines. Majority of them are shed antlers, but here as well a certain smaller amount of antlers comes from killed animals. Typological repertoire includes massive cutting and percussion tools axes, adzes, chisels, wedges, combined hammeraxes, simple hammers, small percussion tools, and other (Fig. 12). The amount of manufacture waste is considerable - basal parts, beam segments and tines with traces of cutting, sawing, unfinished perforations, etc. Such large quantities certainly point to the very intensive production. One particularly important characteristic of the antler industry from both Sarvaš and Zók are traces of manufacture made by metal tools (cf. Christidou 2008).

Artefacts made from bones include simple forms of medium, fine and heavy points made from different bones (mainly metapodial bones, tibiae and ribs) from small and large ruminants, as well as spatulae and scrapers made from ribs and chisels from longitudinally split long bones.

Boar tusks, both from wild and domestic pigs, were also relatively frequently used. Majority of these objects were different forms of scrapers, however, they are also fragmented and for most of them it is not possible to reconstruct neither original shape nor the purpose.

Among the artefacts made from antlers also should be outlined toggle harpoons, very nicely made. Tog- 
rističnim za kasni eneolitik i brončano doba Karpatskoga bazena. Primjerci iz vučedolske kulture svi su jako pažljivo izrađeni, primjetna je kako vještina majstora koji ih je izradio, tako i veliko ulaganje vremena i truda, što pokazuje da se radi o cijenjenim predmetima. Izrađeni su od samog vrha paroška roga jelena, imaju bazu ukoso odrezanu, perforaciju smještenu u mezijalnom dijelu i masivan, oštar šiljak. Vjerojatno su korišteni u ribolovu, moguće za neku posebnu vrstu koja obitava u velikim rijekama u Panoniji, ili se radi o specifičnoj tehnici ribolova.

\section{Diskusija i zaključak}

Tijekom eneolitika, koštane sirovine i dalje predstavljaju jednu od osnovnih sirovina za izradu raznovrsnih predmeta - od svakodnevnih alata, oružja, do ukrasnih i neutilitarnih predmeta.

$S$ jedne strane, i dalje su prisutne neke tehnološke i tipološke odlike preuzete iz neolitičkog perioda, naročito tijekom ranoga i srednjega eneolitika. $S$ druge strane, uočavaju se i znatne promjene.

Javljaju se novi tipovi predmeta, od kojih su neki povezani s novom sirovinom - bakrom. Naime, sad se od dugih kostiju sitnih preživača izrađuju dršci za fine i tanke bakrene predmete, šila i igle. Takvi su nam dršci poznati iz slojeva Kostolac-Coțofeni lokaliteta Bubanj, gdje se izrađuju isključivo od metapodijalnih kostiju ovce/koze. Nalaz s lokaliteta Hisar-Suva Reka vjerojatno također pripada kostolačkim slojevima. Na eneolitičkim lokalitetima u Bugarskoj nešto raznovrsnije sirovine se koriste za drške, mada opet prevladavaju metapodijalne kosti i tibije ovce/koze. Posebno su interesantni primjerci gdje je očuvana bakrena alatka unutar drška, kao što je primjerak s Azmaške mogile (Калчев 2005).

Krupna promjena uočava se i među ukrasnim i neutilitarnim predmetima. Dok je tijekom neolitika u cijeloj jugoistočnoj Europi glina bila osnovna sirovina za izradu antropomorfnih i zoomorfnih figura i drugih predmeta kojima se pretpostavlja ritualna svrha, s rijetkim primjercima od kamena, sada se javljaju i figure od kostiju. To pokazuje da se kulturni odnos prema sirovinama promijenio (cf. Vitezović \& Bulatović 2015). gle harpoons can be considered as characteristic for the Eneolithic period and the Bronze Age in the Carpathian basin. The examples from the Vučedol culture are all very finely made; both the skill of the craftsperson who made them is visible and the investment of time and labour, suggesting that these were valued objects. They were produced from the very tip of the antler tine; their base is obliquely cut, they have the perforation in the mesial part and massive, but sharp point. They were probably used in fishing, perhaps for a particular species that lives in large rivers in the Pannonian plain, or this was for some specific fishing technique.

\section{Discussion and conclusion}

During the Eneolithic, osseous raw materials still represent one of the basic raw materials for production of diverse objects - from everyday tools, weapons, up to decorative and non-utilitarian items.

From one side, some of the technological and typological traits from the Neolithic period are still present, in particular during the early and middle Eneolithic. On the other side, also considerable changes may be noted.

New types of objects now occur, some of them related with the new raw material - copper. Namely, now are produced handles from long bones of small ruminants for fine and slender copper objects, needles and awls. Such handles were found within the Kostolac-Coțofeni layers of the site of Bubanj, where they were made exclusively from metapodial bones of sheep/goat. The find from the site of Hisar-Suva Reka probably also belongs to the Kostolac culture layers. On the Eneolithic sites in Bulgaria somewhat more diverse raw materials are used, but still the metapodial bones and tibiae of sheep/goats prevail. Particularly interesting are examples where the copper tool is still preserved within the handle, such as the example from Azmashka mogila (Калчев 2005).

An important change may be observed among the decorative and non-utilitarian objects. While in the Neolithic period in the entire south-eastern Europe clay was the main raw material for production of anthropomorphic and zoomorphic figurines and other objects for which the ritual purpose is assumed, with rare examples made of stones, now we have figurines made from bones. This shows that the cultural attitude towards raw materials changed (cf. Vitezović \& Bulatović 2015). 
Nakit od importiranih morskih školjki, osobito Spondylus i Glycymeris, karakterističan je za neolitičku Europu (cf. Séfériadès 2010). Količina ovih predmeta sada donekle opada, ali se uočava da se javlja lokalna zamjena - nakit od riječnih školjki Unio. Radionica za izradu ukrasa od školjki Unio otkrivena je u kasno eneolitičkom horizontu Cernavoda III na lokalitetu Bubanj, a školjke Unio kao ukras dosta su dobro zastupljene i na eneolitičkom lokalitetima u Rumunjskoj, kao što je tell Hărşova (Mărgărit 2008).

Tehnologija izrade postupno se mijenja. Dok u badenskoj kulturi još uvijek imamo sigurne tragove obrade kremenim alatom, već se u vučedolskoj kulturi uočava korištenje metalnog alata za obradu rogova.

Osim toga, sama proizvodnja sve je više standardizirana i češće se u arheološkom zapisu prepoznaju radionička mjesta ili radionice, što dalje pokazuje da je proizvodnja intenzivirana, više standardizirana i moguće već djelomično specijalizirana. Radionica ili radioničko mjesto za izradu koštanih figura otkriveno je na lokalitetu Hotnica u Bugarskoj (Ангелов 1961). Mjesta za preradu rogova identificirana su na nekoliko lokaliteta kulture Gumelnița, kao što su Borduşani-Popină (Mărgărit et al. 2009), ili tell Hărşova (Mărgărit \& Popovici 2012), gdje je otkrivena bogata i raznovrsna industrija roga i otpaci od proizvodnje te polufabrikati u različitim stupnjevima obrade.

Industrija roga naročito cvjeta tijekom vučedolske kulture; izrađuje se velika količina predmeta, uključujući i masivne alate poput čekića, kombiniranih perkutera, sjekira, tesli, ali i oružja, kao što su konusni harpuni, koji su zahtijevali posebnu vještinu i uloženi trud i vrijeme u izradu. Radionice ili radionička mjesta, moguće već specijalizirana, postojala su u okvirima naselja na Sarvašu i na Zóku.

\section{* *}

Koštana industrija u eneolitiku nastavlja da živi, mijenja se i razvija; prilagođava se novim potrebama, novim tehnološkim rješenjima i novim sirovinama. Osobito je značajno što se i u koštanoj industriji oslikavaju neke karakteristike društava eneolitičkog razdoblja - intenzivirana proizvodnja, povećana standardizacija i djelomična specijalizacija, ali i pojava novih prestižnih predmeta.
Jewellery from imported marine shells, in particular Spondylus and Glycymeris, is characteristic for the entire Neolithic Europe (cf. Séfériadès 2010). The quantity of these objects is somewhat in decline, but we may observe that the local replacement now occurs - jewellery from river Unio shells. Workshop for making the decorative objects from Unio shells is discovered in the Late Eneolithic horizon of the Cernavoda III culture on the site of Bubanj, and Unio shells as decoration are widespread on the Eneolithic sites in Romania, such as Hărșova tell (Mărgărit 2008).

The technology of production changes gradually. While in the Baden culture we still have certain traces of working with chipped stone tools, already in Vučedol culture we may note the use of metal tools for manufacturing antler objects.

Furthermore, the production itself is more and more standardised and more often in the archaeological record we can recognise working places or workshops, which further shows that the production is intensified, more standardised and probably already partially specialised. The workshop or working place for production of bone figurines is discovered at the site of Hotnica in Bulgaria (Ангелов 1961). Places for working antlers are identified on several sites of the Gumelnița culture, such as Borduşani-Popină (Mărgărit et al. 2009), or Hărşova tell (Mărgărit \& Popovici 2012), where rich and diverse antler industry is discovered, along with manufacture debris and semi-finished items in different stages of production.

The antler industry particularly flourished in the Vučedol culture; a large amount of artefacts are being produced, including massive tools such as hammers, combined percussion tools, axes, adzes, but also weapons, such as toggle harpoons, which demanded particular skill and investment of time and labour into the production process. Workshops or working places, perhaps already specialised, existed in the settlements of Sarvaš and Zók.

The bone industry in the Eneolithic continues to live, it changes and develops; it adjusts to the new needs, new technological solutions and new raw materials. Especially important is that even in the bone industry are reflected some of the main traits of the Eneolithic period - intensified production, increased standardisation and partial specialisation, and also the appearance of new prestigious objects. 


\section{Zahvale}

Zahvaljujem s kolegama na povjerenom materijalu koji je ovdje analiziran, kao i na pomoći u radu: Kazimiru Miculiniću, Sanjinu Miheliću, Jacquelini Balen, Vedrani Krištofić, Dragani Rajković, Tomislavu Hršaku, Aleksandru Bulatoviću i Igoru Jovanoviću.

\section{Literatura / Bibliography}

Andreescu, R. R. 2002, Plastica antropomorfă Gumelnițeană, Muzeul Național de istorie a Romăniei, București.

Ангелов, Н. 1961, Работилница за плоски костени идоли в селищната могила при с. Хотница, Тьрновско, Археология III (2), 34-38.

Averbouh, A. 2000, Technologie de la matière osseuse travaillée et implications palethnologiques, Thèse de doctorat, Université de Paris I, Paris.

Averbouh, A. \& Zidarov, P. 2014, The production of bone figurines in the Balkan Chalcolithic and the use of debitage by extraction, in: M. Mărgarit, G. Le Dosseur \& A. Averbouh (eds.), An overview of the exploitation of hard animal materials during the Neolithic and Chalcolithic, Editura Cetatea de Scaun, Tărgoviște, 183-200.

Barge-Mahieu. H. 1990, Les outils en os emmanchés de l'habitat chalcolithique des Barres (Eyguières, Bouches-du-Rhône) et les tubes en os du Midi de la France", Bulletin de la Société préhistorique française $87 / 3,86-92$.

Berciu, D. 1961, Contribuții la problemele neoliticului in Rominia in lumina noilor cercetâri, Editura Academiei Republicii Populare Romîne, București.

Borrello, M. \& Micheli, R. 2004, Spondylus gaederopus, gioiello dell'Europa preistorica, Preistoria Alpina suppl. 1, vol. 40, 71-82.

Bulatović, A. \& Milanović. D. 2012, Preliminarni rezultati arheoloških iskopavanja na lokalitetu Bubanj u Novom Selu u 2011. godini, in: V. Bikić, S. Golubović i D. Antonović (eds.), Arheologija u Srbiji, projekti Arheološkog instituta u 2011. godini, Arheološki institut, Beograd, 22-25.

Bulatović, A., Milanović, D. \& Vitezović, S. 2014, Preliminarni rezultati istraživanja lokaliteta Bubanj u 2013. godini, in: D. Antonović (ed.), Arheologija u

\section{Acknowledgements}

I would like to thank to the colleagues who entrusted me with the material analysed here and for the help they provided during work: Kazimir Miculinić, Sanjin Mihelić, Jacqueline Balen, Vedrana Krištofić, Dragana Rajković, Tomislav Hršak, Aleksandar Bulatović and Igor Jovanović.

English translation: Selena Vitezović

Srbiji. Projekti Arheološkog instituta u 2013. godini, Arheološki institut, Beograd, 22-25.

Cernea, C., Vlad, F. \& Coman, R. 2014, Primary analyses of the hard animal material industry of the Cernavoda I culture (Săveni-La Movile Site, Ialomița county, Romania), in: M. Mărgarit, G. Le Dosseur \& A. Averbouh (eds.), An overview of the exploitation of hard animal materials during the Neolithic and Chalcolithic, Editura Cetatea de Scaun, Tărgoviște, 275-293.

Choyke, A. M. 1997, The bone tool manufacturing continuum, Anthropozoologica 25-26, 65-72.

Choyke, A. M. 2014, Continuity and discontinuity at Gyõr-Szabadrét-Domb: bone tools from a Chalcolithic settlement in northwest Hungary, in: M. Mărgarit, G. Le Dosseur \& A. Averbouh (eds.), An overview of the exploitation of hard animal materials during the Neolithic and Chalcolithic, Editura Cetatea de Scaun, Tărgoviște, 295-328.

Christensen, M. 2004, Fiches caractères morphologiques, histologiques et mécaniques des matières dures d'origine animale, in: D. Ramseyer (ed.), Matières et techniques. Fiches de la Commission de nomenclature sur l'industrie de l'os préhistorique. Cahier XI, CNRS, Paris, 17-27.

Christidou, R. 2008, The use of metal tools in the production of bone artifacts at two Bronze Age sites of the southwestern Balkans: a preliminary assessment, in: L. Longo \& N. Skakun (eds.), "Prehistoric technology" 40 years later: functional studies and the Russian legacy, Proceedings of the international congress, 20-23 April 2005 Verona, British Archaeological Reports, International Series 1783, Oxford, 253-264.

Christidou, R. \& Legrand, A. 2005, Hide working and bone tools: experimentation design and applicati- 
ons, in: H. Luik, A. M. Choyke, C. Batey \& L. Lõugas (eds.), From Hooves to Horns, from Mollusc to Mammoth - Manufacture and Use of Bone Artefacts from Prehistoric Times to the Present. Proceedings of the 4th Meeting of the ICAZ Worked Bone Research Group at Tallinn, 26th-31st of August 2003, Muinasaja teadus 15, Tallinn, 385-396.

Comşa, E. 1976, Date despre un tip de figurină neolitică de os, Studii și cercetari de istorie veche 27 (4), 557-564.

Comşa, E. 1979, Les figurines en os appartenant à la phase moyenne de la culture Gumelnița, Dacia (n. s.) XXIII, 69-78.

d'Errico, F. 1993, Identification des traces de manipulation, suspension, polissage sur l'art mobilier en os, bois de cervidés, ivoire, in: P. C. Anderson, S. Beyries, M. Otte \& H. Plisson (eds.), Traces et fonctions: les gestes retrouvés, vols 1-2, Centre de Recherches Archéologiques du CNRS, Études er Recherches Archéologiques de l'Université de Liège (ERAUL 50), Liège, 177-188.

Gál, E. 2011, Prehistoric antler- and bone tools from Kaposujlak-Vardomb (South-Western Hungary) with special regard to the Early Bronze Age implements, in: J. Baron \& B. Kufel-Diakowska (eds.), Written in Bones. Studies on technological and social contexts of past faunal skeletal remains, Uniwersytet Wrocławski, Instytut Archeologii, Wroclaw, 137-164. Gál, E. 2014, Bone, antler and tusk tools, in: T. Horváth (ed.), The Prehistoric Settlement at Balatonöszöd-Temetöi-dülö: The Middle Copper Age, Late Copper Age and Early Bronze Age Occupation, Archaeolingua, Varia archaeologica Hungarica, Budapest, 327-332.

Гарашанин, М. 1973, Праисторија на тлу СР Србије, Српска књижевна задруга, Београд.

Георгиева П., 2014, Костени антропоморфни фигурки от Козарева могила, in: В. Петрова, С. Танева \& K. Бояджиев (eds.), In memoriam Lilyana PernichevaPerets, Годишник на националния археологически музей 12, София, 225-232.

Hansen, S. 2011, Figurines in Pietrele: Copper Age Ideology, Documenta Praehistorica XXXVIII, 117129.

Kogălniceanu, R., Ilie, A., Mărgărit, M., Simalcsik, A. \& Dumitrașcu V. 2014, A hoard of astragals discovered in the Copper Age settlement at lepureşti, Giurgiu County, Romania, Documenta Praehistorica XLI, 283-304.

Krištofić, V. 2017, Koštana industrija s nalazišta Vučedol iz zbirke Arheološkog Muzeja u Zagrebu, Stručni rad, Arheološki muzej, Zagreb.
Legrand, A. 2007, Fabrication et utilisation de l'outillage en matières osseuses du Néolithique de Chypre: Khirokitia et Cap Andreas-Kastros, Archaeopress, BAR International series S1678, Oxford.

Maigrot, Y. 2003, Etude technologique et fonctionnellede l'outillage en matières dures animalesLa station 4 de Chalain (Néolithique final, Jura, France), Thèse de doctorat, Université de Paris I, Paris.

Manolakakis, L. \& Averbouh, A. 2004, Grandes lames et grandes statuettes, marqueurs de l'activité funéraire dans le Chalcolithique de Bulgarie, in XXVe Congrès Préhistorique de France, Nanterre 24-26 novembre 2000 - Approches fonctionnelles en Préhistoire, Société préhistorique française, Nannterre, 155-165.

Mărgărit, M. 2008, Les perles en valves de Unio dans I'habitat énéolithique de Harșova-tell (départment de Constanța), Annales d'Université „Valahia” Târgoviște. Section d'Archéologie et d'Histoire X, 73-77.

Mărgărit, M., Popovici, D. N. \& Vlad, F. 2009, L'exploitation du bois dans l'habitat énéolithique de Bordușani-Popină (dép. de Ialomița), Annales d'Université „Valahia” Târgoviște. Section d'Archéologie et d'Histoire XI/I, 53-67.

Mărgărit, M. \& Popovici, D. N. 2012, Another facet of man - Red deer relationship in prehistory: Antler exploitation at the Eneolithic settlement at Hârsova-tell (Constanta County, Romania), Documenta praehistorica XXXIX, 397-416.

Meier, J. 2013, More than fun and games? An experimental study of worked bone astragali from two Middle Bronze Age Hungarian sites, in: A. Choyke \& S. O'Connor (eds.), From these bare bones: raw materials and the study of worked osseous objects, Oxbow books, Oxford, 166-173.

Miculinić, K. \& Vitezović, S. 2017, Faunal remains and the bone industry from the Late Eneolithic site Josipovac - Gravinjak, eastern Croatia, At the Gates of the Balkans - Prehistoric communities of the Baranya/Baranja region and the adjacent areas. International round-table conference, 23-24 February 20147, Pécs, 32

Mihelić, S. 2008, Lokalitet: Josipovac - Gravinjak, Hrvatski arheološki godišnjak, 4/2007, https://www.min-kulture.hr/userdocsimages/ HAG_2007_27_1_2010_mala.pdf

Mitrović, J. \& Vitezović, S. 2017, Zók revisited: Excavations of D. Karapandžić at Zók in 1920. Yearbook Of Joanus Pannonius Museum/ Jahrbuch des JanusPannonius-Museums/ A Janus Pannonius Múzeum Évkönyve 54, 179-190. 
Newcomer, M. 1974, Study and replication of bone tools from Ksar Akil (Lebanon), World Archaeology 6/2, 138-153.

Peltier, A. 1986, Étude expérimentale des surfaces osseuses façonnées et utilisées, Bulletin de la Société Préhistorique Française 83/1, 5-7.

Петков, Н. 1950, Класификация на плоските костни идоли в Балкано-дунавската област, Годишник на народния музей Пловдив II, 25-37.

Poplin, F. 2004, Fiche éléments de nomenclature anatomique relative aux matières dures d'origines animale, in: D. Ramseyer (ed.), Matières et techniques. Fiches de la Commission de nomenclature sur l'industrie de l'os préhistorique, Cahier XI, CNRS, Paris, 11-15.

Radu, A. 2002, Cultura Sălcuța în Banat, Editura Banatica, Reșița.

Schibler, J. 2007, Knochen, Zahn, Geweih und Horn: Werkstoffe der prähistorischen und historischen Epochen, Nova Acta Leopoldina Neue Folge 94, 4563.

Séfériadès, M. L. 2010, Spondylus and long-distance trade in prehistoric Europe, in: D. Anthony (ed.), The Lost World of Old Europe: The Danube Valley 50003500BC. Lost world of europe The Danube Valley 5000-3500BC, The Institute for the study of the Ancient World \& Princeton University Press, New York, Princeton \& Oxford, 178-190.

Tasić, N. 1995, Eneolithic cultures of central and west Balkans, Beograd: Draganić.
Тасић, Н. 1998, Хисар код Суве Реке. Вишеслојно насеље, in: Археолошко благо Косова и Метохије од неолита до раног средњег века, Каталог, Галерија Српске академије наука и уметности, Београд, 492501.

Тодорова, Х. 1980, Классификация и числовой код пластики неолита, энеолита и ранней бронзовой эпохи Болгарии, Studia praehistorica 3, 43-64.

Todorova. H. \& Vajsov, I. 2001, Der kupferzeitliche Schmuck Bulgariens. Prähistoriche Bronzefunde 20 (6), Franz Steiner Verlag Wiesbaden GmbH, Stuttgarrt.

Uzelac, J. 2002, Eneolit južnog Banata, Gradski muzej Vršac, Vršac.

Vitezović, S. 2007, Koštana industrija u neolitu srednjeg Pomoravlja, Magistarska teza / Mphil thesis, Univerzitet u Beogradu, Beograd.

Vitezović, S. \& Bulatović, A. 2015, The first find of an early Eneolithic flat bone figurine in the Central Balkans, Zbornik Narodnog muzeja XXII-1, 31-44.

Vitezović, S. \& Mitrović, J. 2016, Antler technology in the Bronze Age: The case study of Zók, in: 11th Meeting of the Worked Bone Research Group of the ICAZ, Programme and abstracts, Iaşi, Romania, 2328. May 2016, Iaşi, 38-39.

Zidarov. P. 2005, Bone artefacts, Acta Archaeologica 76 (1), Acta Archaeologica Supplementa 6, Lîga, Copper Age strategies in Bulgaria, 124-131, 185-187. 